\title{
Entry into working life: Spatial mobility and the job match quality of higher-educated graduates
}

Citation for published version (APA):

Venhorst, V., \& Cörvers, F. (2015). Entry into working life: Spatial mobility and the job match quality of higher-educated graduates. Maastricht University, Graduate School of Business and Economics. GSBE Research Memoranda No. 009 https://doi.org/10.26481/umagsb.2015009

Document status and date:

Published: 01/01/2015

DOI:

10.26481/umagsb.2015009

Document Version:

Publisher's PDF, also known as Version of record

\section{Please check the document version of this publication:}

- A submitted manuscript is the version of the article upon submission and before peer-review. There can be important differences between the submitted version and the official published version of record.

People interested in the research are advised to contact the author for the final version of the publication, or visit the DOI to the publisher's website.

- The final author version and the galley proof are versions of the publication after peer review.

- The final published version features the final layout of the paper including the volume, issue and page numbers.

Link to publication

\footnotetext{
General rights rights.

- You may freely distribute the URL identifying the publication in the public portal. please follow below link for the End User Agreement:

www.umlib.nl/taverne-license

Take down policy

If you believe that this document breaches copyright please contact us at:

repository@maastrichtuniversity.nl

providing details and we will investigate your claim.
}

Copyright and moral rights for the publications made accessible in the public portal are retained by the authors and/or other copyright owners and it is a condition of accessing publications that users recognise and abide by the legal requirements associated with these

- Users may download and print one copy of any publication from the public portal for the purpose of private study or research.

- You may not further distribute the material or use it for any profit-making activity or commercial gain

If the publication is distributed under the terms of Article $25 \mathrm{fa}$ of the Dutch Copyright Act, indicated by the "Taverne" license above, 


\section{Maastricht University}

Viktor Venhorst, Frank Cörvers

Entry into working life: Spatial mobility and the job match quality of higher-educated graduates

RM/15/009

\section{GSBE}

Maastricht University School of Business and Economics

Graduate School of Business and Economics

P.O Box 616

NL-6200 MD Maastricht

The Netherlands 


\title{
Entry into working life: Spatial mobility and the job match quality of higher-educated graduates
}

\author{
Viktor A. Venhorst ${ }^{\mathrm{a}}$ and Frank Cörvers ${ }^{\mathrm{b}}$ \\ ${ }^{a}$ Corresponding author, University of Groningen, Faculty of Spatial Sciences, The Netherlands, tel. +31(0)503638290, v.a.venhorst@ rug.nl \\ ${ }^{\mathrm{b}}$ Maastricht University, Research Centre for Education and the Labour Market (ROA) \& Tilburg University, Research Institute for \\ Flexicurity, Labour Market Dynamics and Social Cohesion (ReflecT), The Netherlands, frank.corvers@maastrichtuniversity.nl
}

\section{March 2015}

\begin{abstract}
We estimate the impact of spatial mobility on job match quality by using a data set of recent Dutch university and college graduates We find positive wage returns related to spatial mobility. However, after controlling for the self-selection of migrants with an IV approach, this effect is no longer significant. We also find that, for our alternative job-match measures, where there is evidence of migrant self-selection, controlling for self-selection strongly reduces the effect of spatial mobility on job match quality. In some cases, the returns on spatial mobility are found to be negative, which may signal forced spatial mobility.
\end{abstract}

Keywords: Regional labor markets; return on spatial mobility; recent graduates JEL classification: J61, R23, J24, I21, J31 


\section{INTRODUCTION}

The inflow of highly able graduates has positive effects on regional development (Faggian and McCann, 2006), making this group highly relevant from a policy perspective. These regional effects are maximized if graduates are able to fully exploit their talents by achieving a good match on the labor market. Recent graduates have been found to be particularly spatially mobile, since, following graduation, they seek to achieve a good match on the labor market to obtain a high return on their educational investment (Venhorst, Van Dijk, and Van Wissen, 2011).

From the economic literature, it is not clear whether migration leads to a better job or whether other factors, such as skill levels and other personal characteristics or economic circumstances in the departure and destination regions, drive the positive association between spatial mobility and financial return that is often found. The literature on the relation between migration and wage returns has considered aspects such as self-selection, information gathering, and regional economic circumstances to explain the return to spatial mobility. In our literature review, we show that, depending on the dominant mechanism, both a positive and a negative relationship between spatial mobility and wages can occur. Moreover, the empirical approaches adopted have been rather diverse (Herzog, Schlottmann, and Boehm, 1993), leading to quite different results. Sometimes substantial positive returns are found, but others report zero or even negative returns. Subtle differences in the specific econometric approach, type of migration, or, more generally, spatial mobility being studied and the nature of the counterfactual could be at the root of these differences.

We acknowledge current insights in the economic literature in different ways. First, to prevent unknown migrant heterogeneity from being a crucial factor in the analysis of the return on migration, we analyze a very homogeneous group of migrants: recent Dutch college and university graduates. Studying this particular group ensures a degree of homogeneity regarding the relation between job change and spatial mobility. Our sample is homogeneous because almost all graduates who complete their education enter the labor market to seek a return on their educational investment. The degree of mobility is the key differential, while various individual demographic and study-related backgrounds also play a role. Similar approaches have been employed by Dahl (2002) for the United States, Eliasson (2011) for Sweden, and Abreu, Faggian, and McCann (2014) for the United Kingdom. Other studies by Gabriel and Schmitz (1995), Yankow (2003), and Détang-Dessendre, Drapier, and Jayet (2004) all focus specifically on younger migrants, albeit with various levels of education. 
Second, from our literature overview, it appears that one needs to control for differences in abilities and skills between individual graduates, as well as differences in economic circumstances in departure or destination regions. Further, one cannot ignore the possibility that individual preferences that are difficult to observe, such as ambition and motivation, play a role as well. We therefore seek to control for self-selection in our analysis. Alongside entering observable characteristics, we attempt to control for unobserved characteristics by taking into account any correlation between the propensity to migrate and outcome in terms of job match.

We contribute to the current literature in two respects. First, we analyze the impact of migration on the quality of the job match, which is a much broader concept than only wage. Other elements of the contract, such as hours worked, whether the job is long term, and a good match with the level of education and academic discipline can be regarded as outcomes of the search process besides salary. We compare the outcomes in terms of wages with alternative job match measures. It is possible that wage rates will not differ much between recent graduates across the country, particularly because of the impact of the system of central wage bargaining and collective labor agreements on wages in the Netherlands (Groot, De Groot, and Smit, 2014). Therefore spatial differences in terms of alternative job match measures may be more profound. Second, we analyze different sub-groups of recent graduates in the labor market. We distinguish between polytechnic or college and university graduates and between males and females. Investing in spatial mobility may be more beneficial for some sub-groups than for others.

The paper's main question is whether finding a job a greater distance away pays off: Does spatial mobility lead to a better job match or are both spatial mobility and job match determined by a third factor? This third factor could be an observable personal characteristic, such as age, gender, or field of study, or an unobservable characteristic, such as ambition or motivation, that influences spatial search effort. We find that, using an ordinary least squares (OLS) model and controlling for ability and other observed personal and regional characteristics, finding work at greater distances from college or university has a positive effect on the wage rate. Similarly, we find a positive effect of spatial mobility on a range of other job match characteristics. Next, we apply an instrumental variable (IV) approach to correct for self-selection. After instrumenting spatial post-graduate mobility by three different variables, including pre-study spatial mobility, we find that the general effect of mobility on wages is no longer significant. With respect to the other job match indicators, we are able to 
show that the effect of post-graduate spatial mobility on the other job match characteristics disappears in many cases or becomes negative.

This paper is organized as follows. In Section 2, we present an overview of the relevant literature. Next, in Section 3, we discuss our estimation strategy and present the data and sample statistics. In Section 4, we present our results regarding the payoff for spatial mobility in terms of wage rates, followed by an elaboration on differences related to gender and a variety of other job match measures. Section 5 discusses the findings and the main conclusions.

\section{LITERATURE REVIEW: THE RETURN ON SPATIAL MOBILITY}

A well-known conclusion from economic analyses of geographic mobility is that migrants move toward regions with higher income levels (Sjaastad, 1962; Borjas, Bronars, and Trejo, 1992). This phenomenon can, in principle, be explained by the theory of compensating wage differentials. Workers desire jobs near their residence and dislike commuting or migrating for jobs. Therefore, in the latter situation, they seek compensation for their discomfort or, more positively formulated, for their investment in migration. Following this line of thinking, a substantial literature has emerged that treats inter-regional migration as a form of spatial job searching. In these studies, a successful outcome is defined not only in terms of income (or improvements therein) but also, for example, as an escape from unemployment. Herzog, Schlottmann, and Boehm (1993) survey the literature and find that, generally, migrants tend to avoid regions with relatively high unemployment rates (Pissarides and Wadsworth, 1989; Herzog, Schlottmann, and Boehm, 1993). Büchel and Van Ham (2003) demonstrate that spatial flexibility reduces the likelihood of being overeducated for one's job.

An alternative theory for explaining higher wages for the more mobile is that certain personal characteristics that influence the likelihood of finding a good job match, such as ability, are correlated with mobility. Human capital theory predicts that returns on investments in job searching will be higher for the more able: Information processing skills, or the ability to learn, increase the likelihood of a successful outcome over and above the effect of a larger spatial search area and the associated increase in opportunities. Higherskilled individuals show higher levels of spatial mobility. Herzog, Hofler, and Schlottmann (1985) distinguish between initial and acquired knowledge, the latter being operationalized as knowledge resulting from past mobility. Their findings suggest that first-time movers have to 
exert greater search effort to make up for their lack of knowledge. Individuals with high human capital do not necessarily possess higher levels of pre-move knowledge but are at an advantage when it comes to acquiring, evaluating, and processing pre-move information. This situation, combined with the higher returns in destination regions, leads to higher rates of spatial mobility for the highly skilled, since it reduces both the costs of migration, as well as the risks of an inferior outcome. However, the informational advantage from prior mobility does not always lead to higher returns. For example, Hunt (2004, p. 845) highlights a group of returning migrants who are identified as a "heterogeneous group of failures and successes" regarding their labor market outcomes.

Demand-oriented theories, however, predict that if employers in a region have an informational advantage above those outside the region, they will be able to attract the best workers in the labor market (Thurow, 1975). Consequently, workers and graduates who are further down the "labor queue," because they are less able and therefore more expensive to train, are forced to leave the region. This unfavorable status could, in turn, lead to lower rather than higher wages in the destination region. In the literature (for example, Smits, 2001), this latter group is sometimes referred to as "forced migrants," sometimes identified by their inferior labor market situation before the move took place or by the inferior outcome of the move itself. In addition, unobserved constraints on mobility-for example, related to one's household situation, a lack of financial means or the opportunity to move, or a preference for staying that outweighs a potentially inferior labor market outcome — could play a role. For these "constrained migrants," inferior outcomes in terms of job match quality could also be observed due to the limited search area.

One potential source of variation in empirical studies is the extent to which they control for self-selection among potential migrants. Borjas, Bronars, and Trejo (1992) elaborate on the work of Roy (1951) and develop a model of migration that serves to explain selection on the basis of the migrants' skill levels. The authors point out that skilled migrants are likely to move into regions where the skills premium is high relative to the local mean wage level. Conversely, low-skilled migrants typically select destination regions where this skills premium is low. The empirical findings suggest that migrants select destinations that feature a reward structure that matches their skills (or lack thereof). Looking at international migration, Borjas (1987) shows that self-selection processes are influenced by factors relating to both the destination area as well as the home region. Hunt and Mueller (2004) study crossborder migration with a sample of US and Canadian workers and find border effects in 
addition to a relationship between skill migration and returns on those skills in some provinces.

Search effort and skills are difficult to capture in survey data, as are other individuallevel effects that are likely to influence both the tendency to be spatially mobile and the return on this behavior. Given this situation, retrospective information on, for example, an individual's income prior to migration has been used in previous studies as a proxy for these unobservables. Gabriel and Schmitz (1995) find support for the idea of favorable selfselection, in the sense that prospective migrants exhibit higher income levels prior to migration than comparable non-migrants do.

In estimating the effect of spatial mobility on wages, researchers can rely on Heckman (1979) selection models or the somewhat more general treatment effects regression models in controlling for selectivity (Maddala, 1983). Nakosteen, Westerlund, and Zimmer (2008) apply this latter approach when attempting to isolate unobserved migrant characteristics. They separately consider observable as well as unobservable characteristics for a sample of Swedish men and women. They find evidence of self-selection based on unobservables, as well as self-selection on the basis of pre-migration income for women, with higher-income women found to be less mobile. Nakosteen and Westerlund (2004) investigate the return on inter-regional migration for previously employed and unemployed groups in a treatment effects framework and find that migration has positive effects on earnings and that there is a negative correlation between the selection and outcome equations. That is, even though the payoff from migration is positive, those with a higher propensity to migrate tend to achieve less favorable wage gains. Smits (2001) initially finds positive returns on migration for a sample of Dutch married men and married women but, after controlling for self-selection, the effect is negative for both groups. The author highlights a less favorable labor market situation for the migrants before they moved. In other words, forced migration and the ensuing less favorable negotiating position could play a role. Similarly, Axelsson and Westerlund (1998) study household migration in Sweden and find no post-migration income gains after correcting for self-selection. The findings of Dostie and Léger (2009), on the other hand, are more in line with Borjas's (1987) selection approach, with Canadian physicians with higher earnings potential more likely to move to regions where the returns to the underlying unobservables are higher.

A related strand of literature discusses the accumulation of skilled employees in regions and finds that skilled regions tend to draw in yet more individuals with high human capital. Agglomeration effects and the resulting increases in productivity and wages are put 
forward as an explanation (Berry and Glaeser, 2005; Faggian and McCann, 2006). Scott (2010) discusses how different types of human capital accumulate in different areas, according to the nature of the skills involved. Analyzing a sample of young French migrants, Détang-Dessendre, Drapier, and Jayet (2004) find that skilled migrants from regions with relatively small labor markets positively self-select for migration toward areas with more sizeable labor markets.

Other contributions point to two methodological issues that could be behind this diversity in results: the time horizon and the selection of appropriate reference groups. Krieg (1997) studies the return on migration for up to three years after migration, specifically taking into account whether migrants changed occupations, employers, or both. Migrants who do not change employers can be thought of as taking a "low-cost migration avenue" (Hunt, 2004, p. 832). Krieg (1997) notes that not taking these different types of migration properly into account biases the relationship found between migration and payoff. The author finds virtually no evidence for remaining selection effects once these aspects are included. Yankow (2003) investigates the return on migration over time in a study on migrant versus nonmigrant job changers. The author finds that, relative to the pay of non-migratory job changers, the returns for skilled migratory job changers only became positive after almost two years. Conversely, the author finds immediate returns for low-skilled workers changing jobs and locations. Lehmer and Ludsteck (2011) also highlight the importance of selecting proper reference groups for job changers that only change employer, relative to those who also change regions. The authors find the highest returns for rural-to-urban migrants and for young migrants. Returns on migration only accrue after a time lag for more highly educated workers.

From this overview, we draw three conclusions. First, there can be great heterogeneity between and within groups of migrants and non-migrants. Second, returns on spatial mobility can be either positive or negative, depending on the self-selection of migrants. Third, to obtain unbiased of returns on spatial mobility, it is important to correct for self-selection. Taking into account these points in our empirical analyses, we focus on the relatively homogeneous group of recent Dutch graduates and correct for both observable and unobservable individual characteristics to estimate unbiased returns on spatial mobility. Furthermore, the returns are differentiated by gender, level, and field of study to account for differences in migratory behavior between these groups and expressed in improvements in job match indicators, including higher wages. 


\section{METHOD AND DATA}

\section{Method}

In previous studies on the relationship between migration and the resulting payoff, a number of different econometric strategies have been applied to correct for endogeneity between the migration decision and the resulting labor market match. The key issue in these types of analyses is that individuals do not randomly divide into migration and non-migration trajectories. Rather, those individuals that stand to gain the most from such a move are more likely to migrate. Critically, the characteristics that drive this mechanism may be invisible to the researcher. In this paper, we apply an IV approach. The outcome equation can be thought of as having the form

$$
Y_{\mathrm{i}}=X_{\mathrm{i}} \beta+\delta M_{\mathrm{i}}+\varepsilon_{\mathrm{i}}
$$

where the parameter $\delta$ measures the effect of spatial mobility (measured by the variable $M_{\mathrm{i}}$ ) on outcome variable $Y_{\mathrm{i}}$ (in the context of this paper, either the wage rate or an alternative job match indicator), given a set of observed controls $X_{\mathrm{i}}$. Crucially, if endogeneity is an issue, the parameter $\delta$ will be biased, since it captures not only the effect of spatial mobility but also the unobserved characteristics of those who are mobile. For example, if spatial mobility is positively correlated with the propensity to realize a favorable job match for reasons that are unobserved or not included in the model (and hence, with $\varepsilon_{\mathrm{i}}$ ), parameter $\delta$ is biased upward. We thus apply a set of instruments for $M_{\mathrm{i}}$, denoted $Z_{\mathrm{i}}$, which includes all of the variables in $X_{\mathrm{i}}$ as well as a number of additional variables excluded from the outcome equation, using Stata's ivreg2 routine with heteroskedasticity-robust standard errors (Baum, Schaffer, and Stillman, 2007). We aim to measure the effect of spatial mobility not only on wages, but also on a variety of other job match indicators, measured as dichotomous variables. In these instances, we apply linear probability models (LPMs) rather than probit or logit models. There are clear disadvantages associated with LPMs. Most importantly, their range is not constrained to the $[0,1]$ interval. However, we are interested in the direct comparison of the marginal effect of spatial mobility with wage outcomes and therefore wish to apply a uniform IV framework to all outcome variables.

\section{Data and Job Match Measures}

Sample. In our analysis, we use data drawn from the Research Centre for Education and the Labour Market (ROA) School-leaver Information System (ROA-SIS) on recent 
college and university graduates. Each year, a cohort of graduates is surveyed that reflects a representative cross section. Graduates are surveyed approximately 18 months after they have graduated. Extensive information is collected on both the graduates' educational backgrounds, as well as their current jobs, including self-employment. The information on the current job includes income, hours worked, contract type, and a variety of other indicators of job match quality. Data from the 2006 to 2008 cohorts of this annual survey are used because these years included information on the graduates' pre-higher education home regions. All universities and most colleges participated in the survey these years, resulting in nearcomplete coverage of the Netherlands. Further, we select only graduates aged between 20 and 30 who participated in full-time education. These constraints are imposed to obtain a more homogeneous sample. This yields a sample of approximately 17,600 college graduates and 8,500 university graduates.

Our sample excludes those graduates who were unemployed at the time of the survey. However, given that the unemployment rate among recent graduates was low, we would not expect this to affect our results. We control for time spent in unemployment before the current job. In addition, our analysis does not include graduates who, at the time of the survey, were still active in follow-up education, such as an additional master's program. Participating in follow-up education could be seen as an additional investment in human capital, for which a return from the labor market can be expected, although it may take some time before these benefits materialize. Those who are still enrolled in full-time follow-up programs often work in low-skilled part-time jobs that do not reflect any attempt at a proper job match. In our analysis, we control for previous participation in follow-up education by graduates who successfully completed such a program by the time of survey.

From earlier research (Venhorst, Van Dijk, and Van Wissen, 2010), it is apparent that the propensity to migrate differs considerably between university and college graduates and, therefore, we analyze college and university graduates separately. Table 1 consequently presents sample statistics on endogenous and exogenous variables separately for college and university graduates.

Endogenous Variables: Job Match Quality and Spatial Mobility. In this section, we discuss our measures for the quality of the job match and spatial mobility. First, we follow the literature by using the natural $\log$ of the hourly wage rate as a dependent variable. However, especially for the group of new entries on the labor market studied in this paper, income differences could be limited. This is not only because these individuals are still at the 
beginning of their careers but also a result of central wage bargaining arrangements, which are common in the Netherlands.

Therefore, alongside wage rate, we also study the effect of spatial mobility on a wider range of job match measures that could also be relevant as elements of a job offer. We do not expect that all aspects of a job match are equally sought after or important for young starters. In fact, differences in the return on spatial mobility for these various job match measures could be indicative of the willingness to move to acquire an improvement in a specific aspect of the job. We investigate whether spatial mobility increases the likelihood of acquiring a job that comes with a permanent contract, a job that is full-time, and at the corresponding level of education (a vertical match) and in the appropriate field (a horizontal match). To these measures, we add two somewhat subjective measures of job match quality. First, we include the respondents' own assessment of the match between their education and the job requirements. Respondents were asked whether they felt that their job matched the skills they acquired at college or university. Second, we used the answer to the question "Are you currently looking for another job?" as a very general indicator of job match. The first of these is a rather specific measure of the perceived quality of the job match, whereas the latter could be related to a host of other job- and non-job-related factors; that is, graduates could be looking at other job options for reasons unrelated to their current job. It is nevertheless of interest to assess the impact of spatial mobility on such a more general indicator of job satisfaction.

Table 1 shows that even though, on average, college graduates earn slightly less than their university counterparts, they do marginally better in terms of the other objective job match indicators, with the exception of having a full-time job. Differences between the groups were smallest for the subjective indicators self-evaluation of job match and not looking for other work.

TABLE 1: Sample Statistics: College and University Graduates

\begin{tabular}{|c|c|c|c|c|c|c|c|c|}
\hline & \multicolumn{4}{|c|}{ College } & \multicolumn{4}{|c|}{ University } \\
\hline & Mean & Std. Dev. & Min & Max & Mean & Std. Dev. & Min & Max \\
\hline \multicolumn{9}{|l|}{ Job match indicators } \\
\hline ln(Hourly wage) & 2.55 & 0.24 & 0.62 & 4.55 & 2.71 & 0.21 & 1.28 & 4.36 \\
\hline Permanent contract & 0.58 & & 0 & 1 & 0.53 & & 0 & 1 \\
\hline Full-time job & 0.75 & & 0 & 1 & 0.82 & & 0 & 1 \\
\hline Vertical match & 0.83 & & 0 & 1 & 0.58 & & 0 & 1 \\
\hline Horizontal match & 0.81 & & 0 & 1 & 0.72 & & 0 & 1 \\
\hline Good match & 0.77 & & 0 & 1 & 0.76 & & 0 & 1 \\
\hline Not looking for another job & 0.83 & & 0 & 1 & 0.82 & & 0 & 1 \\
\hline \multicolumn{9}{|l|}{ Spatial mobility } \\
\hline Rel. mobility study to job loc. & 0.85 & 0.83 & 0.00 & 11.47 & 0.77 & 0.73 & 0.00 & 8.54 \\
\hline
\end{tabular}




\begin{tabular}{|c|c|c|c|c|c|c|c|c|}
\hline Rel. mobility home to study loc. (instr.) & 1.02 & 0.95 & 0.00 & 9.38 & 1.03 & 0.75 & 0.00 & 8.15 \\
\hline Lived in core at age 16 (instr.) & 0.40 & & 0 & 1 & 0.45 & & 0 & 1 \\
\hline \multicolumn{9}{|l|}{ Demographics } \\
\hline Male & 0.43 & & 0 & 1 & 0.46 & & 0 & 1 \\
\hline Age & 24.50 & 1.83 & 20 & 30 & 26.31 & 1.72 & 21 & 30 \\
\hline Foreign-born EU & 0.01 & & 0 & 1 & 0.02 & & 0 & 1 \\
\hline Foreign-born non-EU & 0.02 & & 0 & 1 & 0.02 & & 0 & 1 \\
\hline Parent(s) foreign born (instr.) & 0.08 & & 0 & 1 & 0.09 & & 0 & 1 \\
\hline \multicolumn{9}{|l|}{ Human capital } \\
\hline Low grade $[6,7>$ & 0.12 & & 0 & 1 & 0.09 & & 0 & 1 \\
\hline Medium grade $[7,8>$ (ref.) & 0.65 & & 0 & 1 & 0.68 & & 0 & 1 \\
\hline High grade $[8,10]$ & 0.23 & & 0 & 1 & 0.23 & & 0 & 1 \\
\hline Study duration in months & 47.24 & 11.51 & 6 & 120 & 54.18 & 27.24 & 1.00 & 143.00 \\
\hline Internship & & & & & 0.70 & & 0 & 1 \\
\hline Relevant work experience & 0.51 & & 0 & 1 & 0.47 & & 0 & 1 \\
\hline Student board experience & 0.20 & & 0 & 1 & 0.39 & & 0 & 1 \\
\hline Study abroad & 0.07 & & 0 & 1 & 0.16 & & 0 & 1 \\
\hline Internship abroad & 0.15 & & 0 & 1 & 0.18 & & 0 & 1 \\
\hline Follow-up education & 0.11 & & 0 & 1 & 0.10 & & 0 & 1 \\
\hline \multicolumn{9}{|l|}{ Transition study to job } \\
\hline Duration finals - questionnaire, months & 18.19 & 3.12 & 12 & 31 & 18.68 & 3.80 & 12 & 30 \\
\hline Months unemployed & 0.97 & 2.30 & 0 & 19 & 1.40 & 2.57 & 0 & 18 \\
\hline \multicolumn{9}{|l|}{ Regional economic characteristics } \\
\hline \# Suitable jobs dest. t-1 $(/ 1,000,000)$ & 0.28 & 0.14 & 0.03 & 0.48 & 0.32 & 0.12 & 0.06 & 0,48 \\
\hline Mean housing value dest. t-1 $(/ 100,000)$ & 0.11 & 1.23 & -3.00 & 1.60 & 0.47 & 1.03 & -3.00 & 1,60 \\
\hline Reg. econ. growth rate dest. t-1 (\%) & 0.18 & 1.21 & -5.60 & 5.20 & 0.22 & 0.92 & -5.60 & 1,90 \\
\hline Reg. unempl. rate grads. dest. t- $1(\%)$ & 4.13 & 1.31 & 0.00 & 7.13 & 3.57 & 1.12 & 0.32 & 5,83 \\
\hline \multicolumn{9}{|l|}{ Year of observation and field of study } \\
\hline 2006 (ref.) & 0.35 & & 0 & 1 & 0.42 & & 0 & 1 \\
\hline 2007 & 0.29 & & 0 & 1 & 0.37 & & 0 & 1 \\
\hline 2008 & 0.36 & & 0 & 1 & 0.20 & & 0 & 1 \\
\hline Agriculture & 0.04 & & 0 & 1 & 0.06 & & 0 & 1 \\
\hline Teaching & 0.13 & & 0 & 1 & & & & \\
\hline Engineering & 0.21 & & 0 & 1 & 0.17 & & 0 & 1 \\
\hline Economics & 0.34 & & 0 & 1 & 0.19 & & 0 & 1 \\
\hline Healthcare & 0.10 & & 0 & 1 & 0.10 & & 0 & 1 \\
\hline Behavioral sciences (ref.) & 0.16 & & 0 & 1 & 0.24 & & 0 & 1 \\
\hline Humanities & & & & & 0.10 & & 0 & 1 \\
\hline Law & & & & & 0.08 & & 0 & 1 \\
\hline Natural sciences & & & & & 0.06 & & 0 & 1 \\
\hline Valid $N$ & 17,665 & & & & 8,531 & & & \\
\hline
\end{tabular}

The spatial mobility variable for relative mobility study to job location $\left(M_{\mathrm{i}}\right)$ is the main explanatory variable, which is, however, endogenous. Therefore, it has to be instrumented. In the context of this paper, it is a variable that describes a graduate's spatial mobility behavior relative to the graduate's peer group. Our focus is on a move from the study location to the job location. The major economic area in the Netherlands is around the larger cities in the western part of the country, which also has the highest density of colleges and universities. For graduates from these educational institutions, high spatial mobility is not required to access opportunity-rich labor markets (see also Venhorst, Van Dijk, and Van Wissen, 2011). Therefore, we need to look at migratory behavior in a relative sense, that is, is a graduate more spatially mobile than the graduate's peer group? The peer group consists of 
all other college or university graduates from the same NUTS 2 study region who graduated in the same academic discipline and in the same year. We have $M_{\mathrm{i}}>1$ if the distance covered by graduate $i$ is greater than the average distance covered by the peer group. ${ }^{1}$ The variable thus captures whether the graduate has opted for greater spatial mobility to access a better job location than graduates in similar situations have.

Independent Variables. Our earlier review of the literature suggested a number of potentially relevant explanatory and control variables. These include measures of skills, controls for regional economic circumstances, and demographic characteristics. Below, we present the exogenous variables that, on this basis, are included in our analysis.

First, we are interested in the effect of ability in a broad sense, since, from the literature, it is clear that human capital factors could be the driving force behind spatial mobility and job match quality. We therefore include dummies for graduation grades to control for academic ability. However, Venhorst, Van Dijk, and Van Wissen (2010) consider the relationship between academic discipline, ability, and migratory propensity among Dutch college and university graduates and find that graduates with higher final grades are not necessarily more mobile. For some fields of study, a labor queue model appears to reflect the observed patterns, with the better graduates achieving good local matches while others have to move elsewhere. This phenomenon also relates to the apparent instances of "forced spatial mobility" found in some of the studies discussed earlier. The returns on spatial mobility could therefore differ substantially between graduates with different human capital characteristics.

Furthermore, given that our sample is made up of new entrants to the labor market and the somewhat modest effects of the graduation grade on spatial mobility found by Van der Klaauw and Van Vuuren (2010), it may be useful to control for other factors that enhance human capital, such as managerial experience (within student societies), internships (included only for university graduates, since virtually all college graduates serve in internships), and relevant work experience or experience abroad, since these could be valued by employers when selecting young employees. We also control for time spent completing the college or

\footnotetext{
${ }^{1}$ We opted to delineate migratory groups based solely on relative distance traversed. No additional regional, border, or distance-based thresholds were imposed that would have to be exceeded before someone was referred to as relatively mobile. Any such additional thresholds would have been difficult to specify in a space-neutral way (having taken regional specifics out of the equation by computing a relative measure) and hence would run the risk of being arbitrary. In terms of robustness checks, we also analyzed the return on spatial mobility using non-relative measures, such as a dummy indicating whether a graduate left the administrative region (NUTS 1, 2 , or 3) of study. The results are similar, albeit that selection becomes less of an issue as we reduce the stringency of the spatial mobility threshold. Naturally, if regional classifications become sufficiently small, everyone becomes spatially mobile.
} 
university program, as a more general measure of skill. This information is combined with the dummy variables for graduation grades to control for observed effects related to human capital, with higher levels of human capital expected to positively influence job match quality.

Second, it is essential to control for the opportunities and constraints present in the working region, since these alter the negotiation balance between employers and job seekers. From Cörvers, Hensen, and Bongaerts (2009), we conclude that these labor market indicators could be sensibly entered at the level of the NUTS 2 working regions. These regional variables are entered with a one-year lag and are assumed as a given for individual graduates. They are entered for the NUTS 2 region (i.e., province) of the current job and are intended to capture the effects of amenities and general economic and labor market circumstances on spatial mobility and job match quality. Our regression analyses include four different exogenous regional variables.

First, we enter the number (in millions) of workers in higher and scientific jobs in a region's active labor force. This measure of the labor market reflects the number of relevant job opportunities in the working region.

Second, we enter the region's relative cost of living $\left(C O L_{\mathrm{i}, \mathrm{t}}\right)$, operationalized by taking the average value, at the NUTS 2 level, of family homes as a percentage of the national average. If $P_{\mathrm{i}, \mathrm{t}}$ is the average house price in region $i$ at time $t$, then

$$
C O L_{\mathrm{i}, \mathrm{t}}=\left(P_{\mathrm{i}, \mathrm{t}}-P_{\mathrm{NL}, \mathrm{t}}\right) / P_{\mathrm{NL}, \mathrm{t}}
$$

The result is a variable with values generally close to zero, with positive values indicating that housing prices in that region are relatively high.

Third, the regional economic growth rate (REGG) is included, again relative to the national growth rate. This results in a variable with a zero mean and positive values for regions with above-average development. If $R_{\mathrm{i}, \mathrm{t}}$ is the growth rate of the regional gross domestic product and $R_{\mathrm{NL}, \mathrm{t}}$ is the growth rate of the national gross domestic product at time $t$, then

$$
R E G G_{\mathrm{i}, \mathrm{t}}=R_{\mathrm{i}, \mathrm{t}}-R_{\mathrm{NL}, \mathrm{t}}
$$

Fourth, the regional unemployment rate, $U_{\mathrm{i}, \mathrm{t}}$, calculated specifically for recent college and university graduates, is entered in the model as a measure of prevailing labor market conditions, based upon the work of Van der Klaauw and Van Vuuren (2010). They find labor 
market conditions, such as the unemployment rate, to be important explanatory factors in their study of Dutch graduates, rather than the effect of graduation grade on income or diverting effort from studying to finding a good job in the final year of studies. Using the ROA-SIS dataset, we compute $U_{\mathrm{i}, \mathrm{t}}$ as the percentage of college or university graduates notionally within the labor force but looking for work.

Wages are generally expected to be higher in larger labor markets, which usually contain large cities, so, we expect to find agglomeration externalities in line with the literature (Groot, De Groot, and Smit, 2014). Wages are also expected to be higher in regions that are relatively expensive to live in, regions with lower unemployment rates, and regions boasting higher economic growth rates. We would generally expect similar effects on the job match measures.

We also control for the length of the period between the time of graduation and the time of the survey (in months). Although graduates are surveyed approximately 18 months after graduation, there is some variation. Within a graduation cohort, which spans a year, some receive their diploma relatively early and some later. As a result, some graduates start the job matching process earlier than others do, with the possible consequence of finding a better match, possibly through greater mobility. Further, we control for the period of unemployment before employment (months). We would expect longer waiting times to lead to both a lower reservation wage as well as an increase in the likelihood of moving. Finally, we introduce dummy variables for the year of observation and the study field.

Instrumental Variables. We apply three IVs: a dummy indicating whether a graduate lived in the central economic region of the Netherlands at age 16, a dummy indicating whether the graduate has one or more parents born outside the Netherlands, and the relative degree of spatial mobility before the onset of graduate-level studies. These variables capture unobservable characteristics, such as ambition or motivation, which influence spatial search effort. Theoretically, living in the opportunity-rich core region at age 16 could affect later search behavior both positively (greater awareness of possibilities) as well as negatively (these possibilities are available nearby). Having a foreign-born parent could lower the psychological costs of being spatially mobile. Previous research finds that those who have been mobile in the past are more likely to move again (DaVanzo and Morisson, 1981). A past migrant has previously incurred the cost of moving and, additionally, in the case of a returning migrant, has existing knowledge of the destination region. 
Spatial mobility before the onset of study, as measured here, reflects the distance between a student's home region (residential area at age 16) and the study location. Defining the home region in this manner, rather than using the region of birth, for example, better reflects the theoretical decision making and spatial information gathering framework that underlies this variable (Newbold, 2001). Relations with the area of birth could have weakened over time, whereas the degree of spatial awareness is likely to be fairly high by the age of 16. Like post-graduate relative spatial mobility, it is measured in relative terms: Each individual is compared to a peer group of students from the same graduation cohort and hailing from the same home region who enrolled in the same field of study at the same (college or university) level. We enter the ratio of the distance moved by graduate $i$ to the average distance traversed by the peer group, excluding graduate $i$. Values greater than one indicate relatively high levels of spatial mobility, whereas values between zero and one indicate below-average levels of spatial mobility. The mean value for our sample is close to one but not exactly one, as could have been expected. ${ }^{2}$

These three IVs are required to be unrelated to the job match element being studied in the outcome equations. We formally test whether this requirement is satisfied for the three variables in the treatment effects models. In some cases, one of the variables does not meet the requirement and is consequently also added to the outcome equation. Table A.1 in Appendix A includes the results for the relevant identification tests. Table A.1 shows that the resulting specifications satisfy the relevant tests; that is, the selected variables are rightly excluded from the outcome equation while, at the same time, strongly identifying a propensity for mobility.

\section{MULTIVARIATE RESULTS}

\section{Wage Equation}

In this section, we discuss the estimation results for the impact of geographic mobility on hourly wage rates, controlling for various characteristics and the endogeneity of the spatial mobility variable. Table 2 shows an OLS model that does not take into account endogeneity, the IV first stage for relative spatial mobility, and the IV outcome equation, all for the total sample of college graduates.

\footnotetext{
${ }^{2}$ This is a result of both weighting the raw data to better match the true graduate population, as well as adjusting the observed means for those graduates whose peer group consists of fewer than 10 members. In these cases, graduates were assigned peer values derived from more aggregated levels, such as the larger NUTS 1 region rather than the NUTS 2 region.
} 
The top row in Table 2 shows the results for the main variable of interest: relative spatial mobility from the study location to the job location. The coefficient $\delta$ shows strikingly different results between the OLS model and the IV regression. In the OLS model, this effect is positive and statistically significant. The exogeneity of relative spatial mobility is rejected, however (Table A.1). Therefore, we turn to our IV setup. Here we find that the effect of postgraduate mobility on wages is insignificant; that is, after both selection and the effect of the other covariates are controlled for, spatial mobility has no effect on the wage rate of college graduates. This suggests that the positive payoff for spatial mobility for this group suggested by the OLS model, which also controls for observed characteristics, is due not to the move as such but, rather, to individual unobserved characteristics that make both higher wages as well as spatial mobility more likely.

The other estimated coefficients in the wage equation are very similar in both outcome models. Wage rates are found to be higher for males, those with above-average grades, those with experience as a member of a student board (IV only), and those with relevant work experience. In addition, wages are higher for those working in larger labor markets and more expensive regions. However, wage rates are negatively affected by an internship abroad, perhaps because graduates find it more difficult to reacquaint themselves with the Dutch labor market. An alternative possibility is that foreign experience is not valued by employers to the extent that this group of graduates anticipated. Completing a follow-up education program does not have a significant effect on wages. This could be because, given the source of the data used, these additional programs were generally only completed shortly before the survey and it takes more time to reap the benefits of this investment. Wages are also found to be lower for those with a longer period of unemployment before finding a job and for graduates in the fields of agriculture, economics, and teaching (relative to the reference category of graduates in the behavioral sciences). Wages are higher in regions with more job opportunities and regions with a higher cost of living.

The IV first stage provides some insight into what drives spatial mobility among college graduates. The variable $M_{\mathrm{i}}$ is positively related to having completed an internship abroad, to the length of time unemployed before finding work, and for destination regions with relatively expensive housing and negatively related to regions with many job opportunities. The latter effect, especially, is driven by those that do not move. A strong positive effect is found for pre-study mobility. Since the graduation year and field of study are also used to construct the spatial mobility of peer groups, the effects found for these 
dummies are slightly more difficult to interpret. The dummy coefficient estimates reflect within-group distributions rather than interesting between-group differences, where negative significant values indicate that, within a field, a lower share of graduates is exceptionally more spatially mobile than in the reference category of behavioral science students. It does not tell us whether the group as a whole is very mobile or not. Elsewhere, it has already been demonstrated that, indeed, mobility differences exist between fields of study (Venhorst, Van Dijk, and Van Wissen, 2010).

Table 3 shows the corresponding results for university graduates. In the OLS model, we find a positive effect of relative spatial mobility that is 2.5 times higher than the effect found for college graduates. This effect disappears in our IV setup of our model, which is the preferred specification, since the exogeneity of spatial mobility is once more rejected (Table A.1). That is, the positive effect of spatial mobility on wage rates found in the OLS specification is driven by issues of selection rather than being a direct effect of spatial mobility as such.

TABLE 2: Estimation Results (College Graduates): OLS and IV Models of ln(Hourly wage)

\begin{tabular}{|c|c|c|c|c|c|c|c|c|c|}
\hline \multirow[b]{2}{*}{ Spatial mobility } & \multicolumn{3}{|c|}{$\begin{array}{c}\text { In(Hourly wage) } \\
\text { College total }\end{array}$} & \multicolumn{3}{|c|}{$\begin{array}{l}\text { IV - First Stage } \\
\text { Rel. mobility study to } \\
\text { job loc }\left(M_{i}\right)\end{array}$} & \multicolumn{2}{|c|}{$\begin{array}{c}\text { In(Hourly wage }) \\
\text { College total }\end{array}$} & $\begin{array}{l}\text { ige) } \\
\text { al }\end{array}$ \\
\hline & $\mathrm{b}$ & se & sig & $\mathrm{b}$ & se & sig & $\mathrm{b}$ & se & sig \\
\hline Rel. mobility study to job loc. $(\delta)$ & 0.010 & 0.002 & $* * *$ & & & & -0.002 & 0.006 & \\
\hline \multicolumn{10}{|l|}{ Demographics } \\
\hline Male & 0.063 & 0.004 & $* * *$ & 0.041 & 0.015 & $* *$ & 0.063 & 0.004 & $* *$ \\
\hline Age & 0.036 & 0.023 & & -0.004 & 0.073 & & 0.037 & 0.023 & \\
\hline Age squared & -0.040 & 0.045 & & 0.000 & 0.146 & & -0.042 & 0.045 & \\
\hline Foreign-born EU & 0.003 & 0.018 & & 0.037 & 0.060 & & 0.005 & 0.018 & \\
\hline Foreign-born non-EU & 0.015 & 0.014 & & 0.076 & 0.049 & & 0.017 & 0.014 & \\
\hline \multicolumn{10}{|l|}{ Human capital } \\
\hline Low grade $[6,7>$ & -0.032 & 0.005 & $* * *$ & 0.008 & 0.018 & & -0.032 & 0.005 & $* * *$ \\
\hline High grade $[8,10]$ & 0.017 & 0.004 & $* * *$ & 0.010 & 0.015 & & 0.017 & 0.004 & $* * *$ \\
\hline Study duration in months & 0.000 & 0.000 & & 0.001 & 0.001 & & 0.000 & 0.000 & \\
\hline Relevant work experience & 0.009 & 0.004 & $*$ & -0.010 & 0.012 & & 0.009 & 0.004 & $*$ \\
\hline Student board experience & 0.008 & 0.004 & & -0.003 & 0.015 & & 0.009 & 0.004 & $*$ \\
\hline Study abroad & 0.003 & 0.007 & & 0.022 & 0.026 & & 0.004 & 0.007 & \\
\hline Internship abroad & -0.011 & 0.005 & $*$ & 0.048 & 0.018 & $* *$ & -0.010 & 0.005 & $*$ \\
\hline Follow-up education & 0.004 & 0.006 & & -0.022 & 0.019 & & 0.003 & 0.006 & \\
\hline \multicolumn{10}{|l|}{ Transition study to job } \\
\hline Duration finals - questionnaire & 0.004 & 0.001 & $* * *$ & 0.004 & 0.002 & $*$ & 0.004 & 0.001 & $* * *$ \\
\hline Months unemployed & -0.009 & 0.001 & $* * *$ & 0.009 & 0.003 & $* *$ & -0.009 & 0.001 & $* * *$ \\
\hline \multicolumn{10}{|l|}{ Regional economic characteristics } \\
\hline \# Suitable jobs dest. t-1 & 0.141 & 0.013 & $* * *$ & -0.460 & 0.067 & $* * *$ & 0.136 & 0.013 & $* * *$ \\
\hline Mean housing value dest. $\mathrm{t}-1$ & 0.004 & 0.002 & $* *$ & 0.048 & 0.006 & $* * *$ & 0.005 & 0.002 & $* *$ \\
\hline Reg. econ. growth rate dest. $\mathrm{t}-1$ & 0.002 & 0.002 & & 0.010 & 0.006 & & 0.002 & 0.002 & \\
\hline Reg. unempl. rate grads. dest. t-1 & 0.000 & 0.002 & & -0.006 & 0.006 & & 0.000 & 0.002 & \\
\hline
\end{tabular}


Time and field of study dummies

Dummy 2007

Dummy 2008

Agriculture

Teaching

Engineering

Economics

Healthcare

Additional instruments

Rel. mobility home to study loc.

Lived in core at age 16

Parent(s) foreign born

Constant

$\mathrm{N}$

R squared

Adj. R squared

$\mathrm{F}$

$* \mathrm{p}<0.1, * * \mathrm{p}<0.05, * * * \mathrm{p}<0.01$

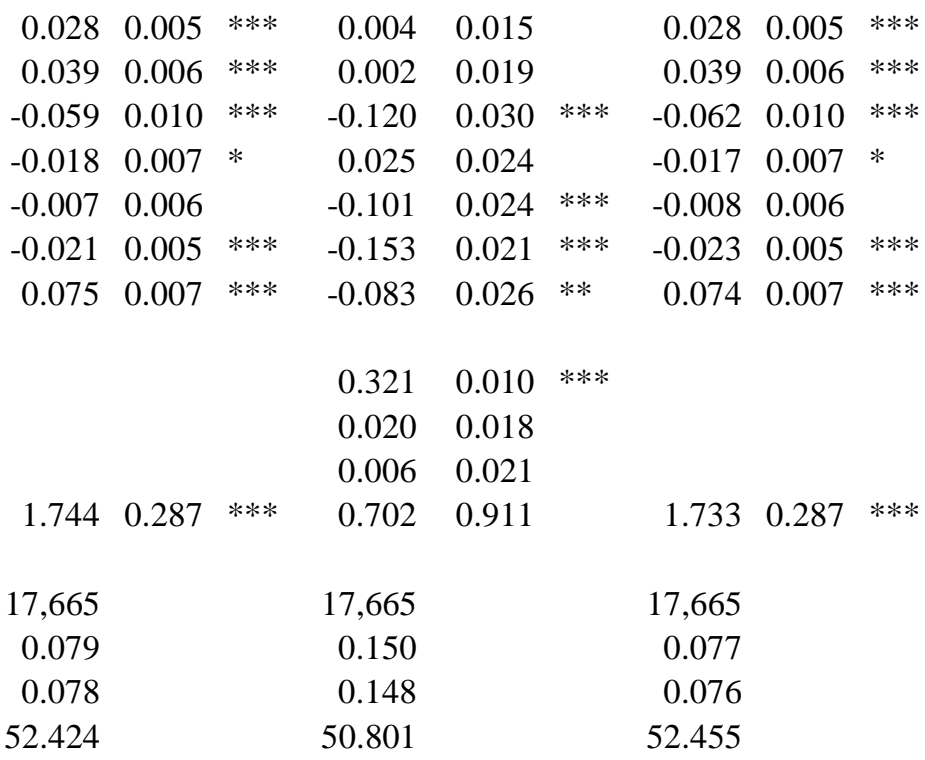

TABLE 3: Estimation Results (University Graduates): OLS and IV Models of $\ln ($ Hourly wage)

\begin{tabular}{|c|c|c|c|c|c|c|c|c|c|}
\hline \multirow{3}{*}{$\begin{array}{l}\text { Spatial mobility } \\
\text { Rel. mobility study to job loc. }(\delta)\end{array}$} & \multicolumn{3}{|c|}{ OLS } & \multicolumn{3}{|c|}{$\begin{array}{l}\text { Rel. Mobility Study } \\
\text { to Job Loc. }\left(M_{i}\right) \\
\text { University Total }\end{array}$} & \multicolumn{3}{|c|}{$\begin{array}{l}\text { In(Hourly wage) } \\
\text { University Total }\end{array}$} \\
\hline & $\mathrm{b}$ & SE & Sig. & $\mathrm{b}$ & SE & Sig. & & SE & Sig. \\
\hline & 0.025 & 0.003 & $* * *$ & & & & -0.012 & 0.016 & \\
\hline \multicolumn{10}{|l|}{ Demographics } \\
\hline Male & 0.034 & 0.005 & $* * *$ & -0.013 & 0.017 & & 0.033 & 0.005 & $* * *$ \\
\hline Age & 0.094 & 0.035 & ** & 0.311 & 0.118 & ** & 0.110 & 0.036 & $* *$ \\
\hline Age squared & -0.149 & 0.066 & $*$ & -0.572 & 0.222 & ** & -0.178 & 0.068 & $* *$ \\
\hline Foreign-born EU & -0.012 & 0.017 & & -0.036 & 0.079 & & -0.013 & 0.018 & \\
\hline Foreign-born non-EU & 0.023 & 0.018 & & 0.016 & 0.064 & & 0.023 & 0.018 & \\
\hline \multicolumn{10}{|l|}{ Human capital } \\
\hline Low grade $[6,7>$ & -0.026 & 0.008 & $* * *$ & 0.005 & 0.027 & & -0.026 & 0.008 & $* * *$ \\
\hline High grade $[8,10]$ & 0.022 & 0.005 & $* * *$ & -0.004 & 0.019 & & 0.022 & 0.005 & $* * *$ \\
\hline Study duration in months & 0.000 & 0.000 & $*$ & -0.001 & 0.000 & $* * *$ & 0.000 & 0.000 & $* *$ \\
\hline Internship & 0.025 & 0.005 & $* * *$ & -0.006 & 0.019 & & 0.025 & 0.005 & $* * *$ \\
\hline Relevant work experience & 0.035 & 0.004 & $* * *$ & 0.016 & 0.015 & & 0.036 & 0.004 & $* * *$ \\
\hline Student board experience & 0.018 & 0.004 & $* * *$ & 0.013 & 0.016 & & 0.020 & 0.004 & $* * *$ \\
\hline Study abroad & -0.005 & 0.006 & & 0.018 & 0.021 & & -0.003 & 0.006 & \\
\hline Internship abroad & 0.014 & 0.006 & $*$ & 0.040 & 0.021 & & 0.016 & 0.006 & $* *$ \\
\hline Follow-up education & -0.010 & 0.008 & & -0.033 & 0.026 & & -0.011 & 0.008 & \\
\hline \multicolumn{10}{|l|}{ Transition study to job } \\
\hline Duration finals - questionnaire & 0.004 & 0.001 & $* * *$ & 0.006 & 0.002 & ** & 0.004 & 0.001 & $* * *$ \\
\hline Months unemployed & -0.011 & 0.001 & $* * *$ & 0.004 & 0.003 & & -0.011 & 0.001 & $* * *$ \\
\hline \multicolumn{10}{|l|}{ Regional economic characteristics } \\
\hline \# Suitable jobs dest. t-1 & 0.207 & 0.023 & $* * *$ & -0.769 & 0.109 & $* * *$ & 0.180 & 0.026 & $* * *$ \\
\hline Mean housing value dest. $\mathrm{t}-1$ & 0.005 & 0.003 & & -0.161 & 0.013 & $* * *$ & -0.001 & 0.004 & \\
\hline Reg. econ. growth rate dest. $t-1$ & -0.005 & 0.003 & & 0.097 & 0.017 & $* * *$ & -0.001 & 0.004 & \\
\hline Reg. unempl. rate grads. dest. t- 1 & -0.001 & 0.002 & & -0.034 & 0.009 & $* * *$ & -0.002 & 0.002 & \\
\hline \multicolumn{10}{|l|}{ Time and field of study dummies } \\
\hline Dummy 2007 & 0.019 & 0.005 & $* * *$ & 0.021 & 0.019 & & 0.020 & 0.005 & $* * *$ \\
\hline Dummy 2008 & 0.024 & 0.007 & $* * *$ & 0.056 & 0.028 & $*$ & 0.027 & 0.007 & $* * *$ \\
\hline
\end{tabular}




\begin{tabular}{|c|c|c|c|c|c|c|c|c|c|}
\hline Agriculture & -0.033 & 0.009 & $* * *$ & -0.388 & 0.026 & $* * *$ & -0.048 & 0.011 & $* * *$ \\
\hline Engineering & -0.003 & 0.007 & & -0.216 & 0.027 & $* * *$ & -0.011 & 0.008 & \\
\hline Economics & 0.063 & 0.007 & $* * *$ & -0.034 & 0.025 & & 0.062 & 0.007 & $* * *$ \\
\hline Healthcare & 0.073 & 0.009 & $* * *$ & 0.015 & 0.032 & & 0.075 & 0.009 & $* * *$ \\
\hline Humanities & -0.080 & 0.009 & $* * *$ & -0.117 & 0.029 & $* * *$ & -0.084 & 0.009 & $* * *$ \\
\hline Law & 0.020 & 0.009 & $*$ & -0.048 & 0.034 & & 0.017 & 0.009 & \\
\hline Natural sciences & 0.000 & 0.010 & & -0.028 & 0.035 & & 0.000 & 0.010 & \\
\hline \multicolumn{10}{|l|}{ Additional instruments } \\
\hline Lived in core at age 16 & -0.008 & 0.004 & & -0.058 & 0.017 & $* * *$ & -0.010 & 0.005 & $*$ \\
\hline Rel. mobility home to study loc. & & & & 0.168 & 0.011 & $* * *$ & & & \\
\hline Parent(s) foreign born & & & & -0.061 & 0.024 & $*$ & & & \\
\hline Constant & 1.047 & 0.463 & $*$ & -3.150 & 1.554 & $*$ & 0.884 & 0.471 & \\
\hline $\mathrm{N}$ & 8,531 & & & 8,531 & & & 8,531 & & \\
\hline R squared & 0.155 & & & 0.097 & & & 0.139 & & \\
\hline Adj. R squared & 0.152 & & & 0.093 & & & 0.136 & & \\
\hline $\mathrm{F}$ & 46.276 & & & 25.867 & & & 44.303 & & \\
\hline
\end{tabular}

The effects of our control variables on wages are partly similar to those found for college graduates. One notable difference is that, next to stronger effects of relevant work experience and experience in student boards, internships abroad now have a positive effect, as do internships in general (an aspect not considered with college students, who virtually all undergo an internship). In another difference with college graduates, we now find a negative effect of study duration on income. We find no effect of the relative housing cost, but, in line with the results for college graduates, university graduate wages are higher in regions with many job opportunities.

From the IV first stage, we see that university graduates are more spatially mobile as the time between graduation and completing the survey increases. However, the length of a pre-work unemployment period has no significant influence. Age is significant and there are also positive effects for having been mobile in the past. Mobility is, on average, lower for university graduates who took a long time to complete their study program. Again, there are differences among the study fields. The additional control variable for living in the core region at age 16 is added to the outcome equation for university graduates, because it failed the exclusion restriction as shown by the Hansen $\mathbf{J}$ tests (Table A.1). In the IV outcome equation, this was found to have a negative effect on wage rates.

\section{Differentiation by Gender and Job Match Indicators}

In this section, we take a closer look at the differences in wage premium for geographic mobility between men and women by running our analysis separately for these groups. We then explore the returns on mobility in terms of other job match aspects rather than wages. 
We analyze the relationship between spatial mobility and wage rate separately for men and women, since the broader literature on labor market participation suggests that labor supply decisions differ between men and women. Earlier work on the spatial mobility of Dutch graduates (Venhorst, Van Dijk, and Van Wissen, 2010, 2011) shows that women have a higher propensity to be mobile than male graduates, especially in considering a move from peripheral areas toward the core region of the Netherlands. Faggian, McCann, and Sheppard (2007) suggest that women have to accept higher levels of spatial mobility to compensate for adverse circumstances in local labor markets. In this light, we would expect women to see higher returns on spatial mobility than men do.

As in the earlier analyses, we include our relative measures of mobility in this section, based on peer groups defined by study field, year of graduation, and university or college location. Additional identifying variables are added to the first-stage equations in the same manner as before. For female graduates from both college as well as university, statistical tests indicate that the variable for having at least one foreign-born parent influences the wage rate. Further, as with the total group of university graduates, the variable having lived in the core region at age 16 is generally found to affect the wage rate for male graduates (Table A.1). These variables are, accordingly, added to the outcome equations.

We furthermore run an analysis to consider alternative job match measures using the full college and university graduate samples. These are measured using dummy variables indicating whether the described quality pertains to the current job (variable equals one) or not (variable equals zero). To facilitate the comparison of wage outcomes, we apply LPMs for the outcome equations, also using Stata's ivreg2 routine. For each outcome and per group, separately, we add those additional IVs that, based on the identification tests reported in Table A.1, are found to be passable. Table 4 presents a summary of the results, restricting our discussion to the main coefficient of interest, ${ }^{3}$ the parameter $\delta$. We also report exogeneity tests for $M_{\mathrm{i}}$, where the zero hypothesis is that spatial mobility is indeed exogenous to the job quality indicator under study.

We start our discussion with the college graduates, as reported in the upper portion of Table 4. The first row repeats the result from Table 2 and shows the effect of mobility on wages for the complete sample of college graduates. Below this, the results of individual estimations for college graduates by gender are shown. We find positive effects of spatial mobility on wages in the OLS specifications for men and women, whereas we find no

\footnotetext{
${ }^{3}$ The models discussed in this section include the same controls as the models for wage rates in Section 4.1. The full specifications are detailed in Appendix B.
} 
statistically significant effects for either group in the IV specifications. The exogeneity of spatial mobility could not be rejected for female college graduates, however, which implies that, for this group and in spite of theoretical considerations that would suggest otherwise, the OLS version of the model suffices. This result implies that, for female college graduates, there is a small positive return to extra spatial mobility: Being twice as mobile as one's peer group produces a $0.7 \%$ wage return.

We find positive effects gained from spatial mobility for both male and female university graduates in the OLS specifications. Comparing male and female university graduates using the baseline OLS models, we see that the parameter $\delta$ is slightly higher for women. Even though this approach does not provide a direct test of the differences in returns on spatial mobility between men and women, this primary OLS result is in line with the expectations regarding women's labor market positions voiced earlier. However, after we control for self-selection, the $\delta$ parameters for both men and women become insignificant. For male university graduates, exogeneity could not be rejected, however $\left(\chi^{2}=1.907 ; \mathrm{p}<\right.$ 0.167); so, again, the results indicate that the OLS interpretation should be followed, implying a $2.4 \%$ higher wage for those that exhibit double the mobility of their peer group. These results are not completely in line with our expectations. Despite their greater mobility, we only find an effect on wages for female college graduates.

TABLE 4: Summary of Estimation Results (Various Samples and Job Match Measures): OLS and IV Models

Effect of Relative Mobility Study to Work Loc.

Naïve OLS / LPM

College
$\ln ($ Hourly wage)
$\ln ($ Hourly wage), women
$\ln ($ Hourly wage $)$, men
p(perm. contr.)
p(full-time)
p(vert. match)
p(hor. match)
p(subj. good match)
p(not looking oth. job)
University
$\ln ($ Hourly wage $)$,
$\ln ($ Hourly wage $)$, women
$\ln ($ Hourly wage $)$, men
p(perm. contr.)
p(full-time)
p(vert. match)

$\delta$

0.010

0.007

0.014

0.000

0.017

0.014

$-0.003$

0.003

0.003

0.025

0.027

0.024

0.028

0.027

0.024
SE Sig.

$0.002 * * *$

$0.003 *$

$0.004 * * *$

0.004

$0.004 * * *$

$0.003 * * *$

0.003

0.004

0.003

$0.003 * * *$

$0.004 * * *$

$0.005 * * *$

$0.007 * * *$

$0.006 * * *$

$0.007 * * *$
IV / LPM, 2nd-Stage Results Test

Exogeneity

\begin{tabular}{rlrrr}
\multicolumn{1}{l}{$\boldsymbol{\delta}$} & SE & Sig. & Chi2 & Sig. \\
-0.002 & 0.006 & & 4.499 & $* *$ \\
0.002 & 0.008 & & 0.470 & \\
-0.008 & 0.009 & & 6.846 & $* * *$ \\
-0.010 & 0.012 & & 0.721 & \\
-0.006 & 0.010 & & 7.056 & $* * *$ \\
0.006 & 0.009 & & 0.809 & \\
-0.055 & 0.010 & $* * *$ & 30.109 & $* * *$ \\
-0.006 & 0.011 & & 0.812 & \\
-0.031 & 0.010 & $* *$ & 13.503 & $* * *$ \\
& & & & \\
& & & & \\
-0.012 & 0.016 & & 5.320 & $* *$ \\
-0.019 & 0.020 & & 5.450 & $* *$ \\
-0.014 & 0.028 & & 1.907 & \\
-0.003 & 0.041 & & 0.614 & \\
0.055 & 0.030 & & 0.922 & \\
0.001 & 0.039 & & 0.377 &
\end{tabular}




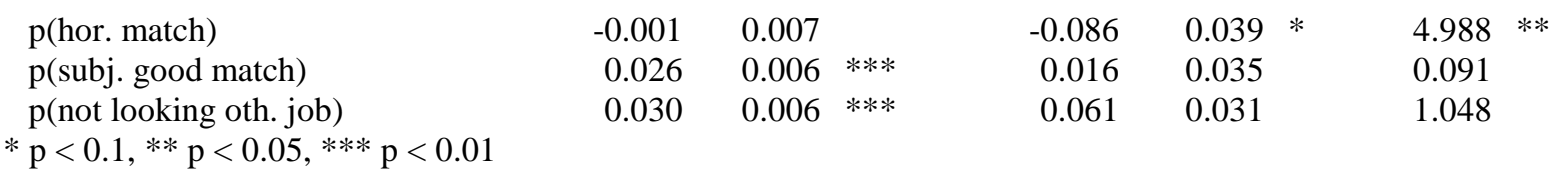

We now turn to the alternative job match measures for college graduates. In the naïve LPMs, the impact of mobility on obtaining a full-time job is positive. We also find a positive effect on finding a job commensurate with one's education level. However, this result is rejected in favor of the insignificant outcome in the IV setup. We find no significant effects of spatial mobility on the probability of a college graduate reporting having a permanent contract or evaluating the job match favorably (naïve LPM or IV setup). We find negative effects of spatial mobility on achieving a match with one's field of study (horizontal match, IV setup preferred). In addition, relatively mobile college graduates are more likely to report that they are looking for other work (IV setup).

The picture that emerges for these other job match aspects is clearer for university graduates. The estimated coefficients for the relationships between spatial mobility and the proposed alternative outcomes are generally positive and significant in the naïve LPMs that do not take endogeneity into account. In the IV setup, all these positive effects are reduced to insignificance, but these IV specifications are rejected, since the exogeneity of spatial mobility cannot be rejected. Overall, university graduates seem to improve their labor match by being geographically mobile. The only exception is found for match with field of work (horizontal match), where we find evidence for endogeneity and a significant negative effect for mobility in the IV setup.

\section{DISCUSSION AND CONCLUSIONS}

We have studied the relationship between spatial mobility and job match quality for a sample of young Dutch recent graduates. The inflow of graduates is often considered an important asset in achieving regional growth. Such benefits are more likely to come to fruition when these graduates are able to achieve a successful match on the regional labor market such that they can fully exploit the investment in their human capital. Examining this specific group allows us to abstract from the confounding issues that have been noted in the literature, such as the relation between job-to-job mobility and spatial mobility, and their effects on job match quality. At the same time, we aim to add to the literature by examining a number of additional job match indicators alongside the more commonplace hourly wage rate. In our analysis, we include a rich variety of observed human capital indicators and 
control for unobserved personal characteristics that may introduce endogeneity into the relationship between spatial mobility and job match quality.

Our primary OLS analysis of mobility and wages showed that relative spatial mobility, for both college and university graduates, has the anticipated significant positive effect on wages, a finding in line with many other studies. In addition, a number of observable human capital indicators plus regional circumstances such as prevailing labor market conditions have strong and consistent effects on wage rates.

However, after controlling for self-selection, using an IV approach, we find that the positive effects of engaging in greater spatial mobility than one's peer group on hourly wage rates are no longer significant for college and university graduates. Whereas economic theory predicts positive returns on migration, our results seem to indicate that a variety of personal and regional factors are key to achieving this benefit — and not the move as such. These factors include observed characteristics such as graduation grades, participation in extracurricular activities, and the scale of the labor market one is entering.

We further analyze this relationship for men and women separately. Here too, initially positive effects from spatial mobility on the wage rate for male college graduates and female university graduates are rendered insignificant after controlling for self-selection. We do find positive returns to spatial mobility for female college graduates and male university graduates. These results are mixed and not completely in line with our expectations, especially for female university graduates, since spatial mobility is often regarded as a means for this particular group to deal with adverse circumstances in local labor markets.

We also analyzed the relationship between spatial mobility and a number of alternative job match indicators that relate to objective characteristics of the contract, such as hours worked, the length of the contract, and horizontal and vertical matching, as well as more subjective evaluations of the match between education and the job.

Even though the evidence on these job match indicators is slightly more mixed than for wages, we again find that, when endogeneity plays a role, controlling for selectivity through IVs generally reduces the observed returns on spatial mobility: Initial positive effects become insignificant and initially insignificant effects become negative and significant. We find evidence that some aspects of job matches (i.e., for college graduates not looking for another job) and field or horizontal matches (for both university and college graduates) are affected negatively by spatial mobility. This could indicate evidence of forced mobility or spatial mobility that is driven by motivations not directly related to labor market outcomes, such as household situation or amenities in the destination region. Our results for horizontal 
matches could also reflect a lower valuation by graduates for these particular outcomes; however, this does not explain the negative effect of looking for another job. In addition, for college graduates, we find no relation with spatial mobility for the outcome of a permanent contract. For university graduates, we do find positive effects of spatial mobility on the likelihood of scoring well for all other alternative job match indicators.

This study demonstrates that, generally, wage returns on spatial mobility are not driven by the move as such but, rather, by other personal and regional characteristics. It also suggests that the job matching process after completing education may be heterogeneous. Particularly for university graduates, spatial mobility is associated with better outcomes on our alternative job match indicators. This is less the case for college graduates, who, as a group, are initially less spatially mobile. Our findings may be the result of a degree of forced spatial job search for part of this group.

In terms of policy, this study concludes that generic labor market measures, especially in less opportunity-rich labor markets, are likely to be of limited efficacy. Specific groups of graduates fail to find a local match and are therefore forced to move to other regions with, at least initially, a poor match as a consequence. This appears to most notably affect college graduates, especially in terms of fixed contracts, jobs in the right field, and general job satisfaction. Targeting labor market information for this group could prove fruitful. However, the more able and perhaps more intrinsically motivated tend to find their way, regardless of circumstances. Policy makers in regions who offer limited opportunities for graduates from local institutions of higher education may be worried that the high returns achievable through spatial mobility are indicative of wide structural problems in their own labor markets. However, as this study demonstrates, these returns on spatial mobility do not generally result from the move as such. Higher education institutions and regional policy makers could try to prevent these moves by retaining the most able recent graduates by offering them attractive jobs in the region. However, this approach may not, per se, lead to higher general national or international income, since those policies can come at the cost of other regions (BertrandCloodt, Cörvers, and Heijke, 2014).

A fruitful avenue for further research could be to include household and partner characteristics, as well as characteristics that are not directly related to labor market entry. These could serve to explain some of the unobserved constraints on spatial mobility or provide rationales for moves that are unexpected from a pure labor market/career perspective, such as the negative relation between spatial mobility and horizontal job matches. 


\section{Acknowledgments}

Earlier versions of this paper were presented during the 2010 NARSC/RSAI conference in Denver, Colorado; a DUHR seminar at the Maastricht University School of Business and Economics, and the 2011 EALE conference in Cyprus. Comments received during these events have greatly improved the work and its presentation. We also thank Ben Kriechel, Raymond Montizaan, Nicolás Salamanca Acosta, Jouke van Dijk and Leo van Wissen for their valuable comments on our paper. Any remaining errors are our own. This research was partially funded by Platform31, the Hague. 


\section{References}

Abreu, M.A., A. Faggian and P. McCann. 2014. "Migration and inter-industry mobility of UK graduates." Journal of Economic Geography, doi: 10.1093/jeg/lbt043

Axelsson, R. and O. Westerlund. 1998. "A Panel Study of Migration, Self-Selection and Household Real Income," Journal of Population Economics, 11(1), 113-126.

Baum, C. F., M. E. Schaffer and S. Stillman. 2007. "ivreg2: Stata Module for Extended Instrumental Variables/2SLS, GMM and AC/HAC, LIML, and k-Class Regression," Boston College Department of Economics, Statistical Software Components S425401, available at http://ideas.repec.org/c/boc/bocode/s425401.html.

Bertrand-Cloodt, D., F. Cörvers and H. Heijke, 2014. "Ability, Academic Climate, and Going Abroad for Work or Pursuing a PhD," Research Memorandum, ROA-RM2014/8, Maastricht University.

Berry, C.R. and Glaeser, E.L. 2005. "The Divergence of Human Capital Levels across Cities," Papers in Regional Science, 83(3), 407-444.

Borjas, G.J. (1987). "Self-selection and the Earnings of Immigrants," American Economic Review, 77(4), 531-553.

Borjas, G.J., S.G. Bronars and S.J. Trejo. 1992. "Self-selection and Internal Migration in the United States," Journal of Urban Economics, 32(2), 159-185

Büchel, F. and M. Van Ham. 2003. "Overeducation, Regional Labor Markets, and Spatial Flexibility," Journal of Urban Economics, 53(3), 482-493.

Cörvers, F., M.M. Hensen and D. Bongaerts. 2009. "Delimitation and Coherence of Functional and Administrative Regions," Regional Studies, 43(1), 19-31.

Dahl, G.B. 2002. "Mobility and the Return to Education: Testing a Roy Model with Multiple Markets," Econometrica, 70(6), 2367-2420.

DaVanzo, J. and P.A Morrison. 1981. "Return and Other Sequences of Migration in the United States," Demography 18(1), 85-101.

Détang-Dessendre, C., C. Drapier and H. Jayet. 2004. "The Impact of Migration on Wages: Empirical Evidence from French Youth," Journal of Regional Science, 44(4), 661-691.

Dostie, B. and P.T. Léger. 2009. "Self-selection in Migration and Returns to Unobservables," Journal of Population Economics, 22(4), 1005-1024.

Eliasson, K. 2011. "Migration and Labor Market Outcomes among Recent College Graduates: Swedish Evidence," Conference of the Western Regional Science Association, February $27^{\text {th }}, 2011$, Monterey, CA.

Faggian, A. and P. McCann. 2006. "Human Capital Flows and Regional Knowledge Assets: A Simultaneous Equation Approach," Oxford Economic Papers, 58(3), 475500.

Faggian, A., P. McCann and S. Sheppard. 2007. "Some Evidence that Women Are More Mobile than Men: Gender Differences in U.K. Graduate Migration Behavior," Journal of Regional Science, 47(3), 517-539.

Gabriel, P.E. and S. Schmitz. 1995. "Favorable Self-selection and the Internal Migration of Young White Males in the United States," Journal of Human Resources, 30(3), 460-471.

Groot, S.P.T., H.L.F. De Groot and M.J. Smit. 2014. "Regional Wage Differences in the Netherlands: Microevidence on Agglomeration Externalities," Journal of Regional Science, 54(3), 503-523.

Heckman, J.J. 1979. "Sample Selection Bias as a Specification Error." Econometrica, 47(1), 153-161. 
Hunt, G.L. and R.E. Mueller. 2004. "North American Migration: Returns to Skill, Border Effects, and Mobility Costs." The Review of Economics and Statistics, 86(4), 9881007.

Herzog, Jr., H.W., R.A. Hofler and A.M. Schlottmann. 1985. "Life on the Frontier: Migrant Information, Earnings and Past Mobility," Review of Economics and Statistics, 67(3), 373-382.

Herzog, Jr., H.W., A.M. Schlottmann and T.P. Boehm. 1993. "Migration as Spatial JobSearch: A Survey of Empirical Findings," Regional Studies, 27(4), 327-340.

Hunt, J. 2004. "Are Migrants More Skilled than Non-Migrants? Repeat, Return, and Same-Employer Migrants," Canadian Journal of Economics, 37(4), 830-849.

Krieg, R.G. 1997. "Occupational Change, Employer Change, Internal Migration, and Earnings," Regional Science and Urban Economics, 27 (1), 1-15.

Lehmer, F. and J. Ludsteck. 2011. "The Returns to Job Mobility and Inter-Regional Migration: Evidence from Germany," Papers in Regional Science, 90(3), 549-571.

Maddala, G.S. 1983. Limited-Dependent and Qualitative Variables in Econometrics, Cambridge: Cambridge University Press.

Nakosteen, R.A. and O. Westerlund. 2004. "The Effects of Regional Migration on Gross Income of Labour in Sweden," Papers in Regional Science, 83(3), 581-595.

Nakosteen, R.A., O. Westerlund and M.A. Zimmer. 2008. "Migration and Self-selection: Measured Earnings and Latent Characteristics," Journal of Regional Science, 48(4), 769-788.

Newbold, K.B. 2001. "Counting Migrants and Migrations: Comparing Lifetime and Fixed-Interval Return and Onward Migration," Economic Geography, 77(1), 23-40.

Pissarides, C.A. and J. Wadsworth. 1989. "Unemployment and the Inter-Regional Mobility of Labour," Economic Journal, 99(397), 739-755.

Roy, A.D. 1951. "Some Thoughts on the Distribution of Earnings," Oxford Economic Papers, New Series, 3(2), 135-146.

Scott, A.J. 2010. "Space-Time Variations of Human Capital Assets across U.S. Metropolitan Areas, 1980 to 2000," Economic Geography, 86(3), 233-250.

Sjaastad, L.A. 1962. "The Costs and Returns of Human Migration," Journal of Political Economy, 70(5), 80-93.

Smits, J. 2001. "Career Migration, Self-selection and the Earnings of Married Men and Women in the Netherlands, 1981-93," Urban Studies, 38(3), 541-562.

Thurow, L.C. 1975. Generating Inequality, New York, Basic Books.

Van der Klaauw, B. and A. Van Vuuren. 2010. "Job Search and Academic Achievement," European Economic Review, 54 (2), 294-316.

Venhorst, V.A., J. Van Dijk and L.J.G. Van Wissen. 2010. "Do the Best Graduates Leave the Peripheral Areas of the Netherlands?" Tijdschrift voor Economische en Sociale Geografie, 101(5), 521-537.

Venhorst, V.A., J. Van Dijk and L.J.G. Van Wissen. 2011. "An Analysis of Trends in Spatial Mobility of Dutch Graduates," Spatial Economic Analysis, 6(1), 57-82.

Yankow, J.J. 2003. "Migration, Job Change, and Wage Growth: A New Perspective on the Pecuniary Return to Geographic Mobility," Journal of Regional Science, 43(3), 483-516. 


\section{APPENDIX A: IV IDENTIFICATION TESTS}

TABLE A.1: Results for Identification Tests

\begin{tabular}{|c|c|c|c|c|c|c|c|c|c|c|}
\hline & \multicolumn{2}{|c|}{ Exogeneity test } & \multicolumn{3}{|c|}{$\begin{array}{l}\text { Instruments Excluded } \\
\text { from 2nd Stage? }\end{array}$} & \multicolumn{2}{|c|}{ Excl. Restrictions } & \multicolumn{2}{|l|}{ UnderID } & \multirow{3}{*}{$\begin{array}{l}\text { Weak ID } \\
\text { Kleibergen- } \\
\text { Paap } \\
\text { rk Wald F- } \\
\text { Statistic } \\
\text { Stat. }\end{array}$} \\
\hline & \multicolumn{2}{|c|}{$\begin{array}{l}\text { H0: Distance } \\
\text { Is Exogenous }\end{array}$} & $\begin{array}{l}\text { Parent(s) } \\
\text { Foreign } \\
\text { Born }\end{array}$ & $\begin{array}{l}\text { Rel. Mobility } \\
\text { Home to } \\
\text { Study Loc. }\end{array}$ & $\begin{array}{l}\text { Lived in } \\
\text { Core at } \\
\text { Age } 16\end{array}$ & Hansen . & Stat. & $\begin{array}{l}\text { Kleibergen } \\
\text { rk LM Sta }\end{array}$ & $\begin{array}{l}\text {-Paap } \\
\text { tistic }\end{array}$ & \\
\hline & Chi2 & Sig. & & & & Stat. & p & Stat. & $\mathbf{p}$ & \\
\hline \multicolumn{11}{|l|}{ College } \\
\hline LN Hourly wage rate (LnWage) & 4,499 & $* *$ & YES & YES & YES & 4.513 & 0.105 & 832,852 & 0.000 & 340,550 \\
\hline LnWage, women & 0,470 & & NO & YES & YES & 1.787 & 0.181 & 530,484 & 0.000 & 305,306 \\
\hline LnWage, men & 6,846 & $* * *$ & YES & YES & YES & 0.260 & 0.878 & 303,272 & 0.000 & 133,183 \\
\hline p(perm. contr.) & 0,721 & & YES & YES & NO & 2.072 & 0.150 & 832,942 & 0.000 & 510,820 \\
\hline $\mathrm{p}$ (full-time) & 7,056 & $* * *$ & YES & YES & YES & 3.634 & 0.163 & 832,852 & 0.000 & 340,550 \\
\hline $\mathrm{p}$ (vert. match) & 0,809 & & YES & YES & NO & 0.834 & 0.361 & 832,942 & 0.000 & 510,820 \\
\hline $\mathrm{p}$ (hor. match) & 30,109 & $* * *$ & NO & YES & NO & N/A & N/A & 832,019 & 0.000 & 1015,835 \\
\hline p(subj. good match) & 0,812 & & YES & YES & NO & 1.999 & 0.157 & 832,942 & 0.000 & 510,820 \\
\hline $\mathrm{p}($ not looking oth. job) & 13,503 & $* * *$ & YES & YES & YES & 1.085 & 0.581 & 832,852 & 0.000 & 340,550 \\
\hline \multicolumn{11}{|l|}{ University } \\
\hline LN Hourly wage rate (LnWage) & 5,320 & $* *$ & YES & YES & NO & 1.247 & 0.264 & 231,293 & 0.000 & 113,116 \\
\hline LnWage, women & 5,450 & $* *$ & NO & YES & YES & 0.037 & 0.848 & 139,135 & 0.000 & 66,336 \\
\hline LnWage, men & 1,907 & & YES & YES & NO & 2.069 & 0.150 & 94,055 & 0.000 & 48,353 \\
\hline p(perm. contr.) & 0,614 & & YES & YES & YES & 0.529 & 0.768 & 234,717 & 0.000 & 77,099 \\
\hline $\mathrm{p}$ (full-time) & 0,922 & & YES & YES & NO & 2.700 & 0.100 & 231,293 & 0.000 & 113,116 \\
\hline $\mathrm{p}$ (vert. match) & 0,377 & & YES & YES & YES & 0.710 & 0.701 & 234,717 & 0.000 & 77,099 \\
\hline $\mathrm{p}$ (hor. match) & 4,988 & $* *$ & NO & YES & YES & 0.021 & 0.886 & 227,025 & 0.000 & 110,932 \\
\hline p(subj. good match) & 0,091 & & YES & YES & YES & 3.625 & 0.163 & 234,717 & 0.000 & 77,099 \\
\hline $\mathrm{p}$ (not looking oth. job) & 1,048 & & YES & YES & YES & 0.889 & 0.641 & 234,717 & 0.000 & 77,099 \\
\hline
\end{tabular}




\section{APPENDIX B: FULL ESTIMATION RESULTS, ALL MODELS}

Tables B.1 to B.3 present the estimation results for the wage analyses according to gender and the estimation results for the alternative job match measures applied in this study. In Table B.1, which contains the analyses of $\ln$ (Hourly wage) for women and men, we report OLS and IV firststage and IV outcome results. In Tables B.2 (college) and B.3 (university), we report only the results for the naïve LPM regressions and the IVLPM outcome equation, since the IV-LPM first-stage results are equal to those reported in Tables 3 and 4 in the main text.

TABLE B.1: College and University Graduates, OLS and IV Analysis of Ln(hourly wage), Men and Women Separately

Spatial mobility

Rel. mobility study to job loc. $(\delta)$ Demographics

Male

Age squared

Foreign-born EU

Foreign-born non-EU

Human capital

Low grade $[6,7>$

High grade $[8,10]$

Study duration in months

Relevant work exp.

Management exp.

Study abroad

Internship abroad

Follow-up education

Transition study to job

Duration finals - questionnaire

Months unemployed

Regional economic characteristics
OLS

$\ln$ (Hourly wage)

College Women

b

$0.007 *$

College Women

b

$\begin{array}{rlr}0.069 & * & 0.057 \\ -0.109 & & -0.135 \\ 0.004 & & 0.006 \\ 0.034 & & 0.000 \\ & & \\ -0.025 & * * & 0.040 \\ 0.012 & * & 0.008 \\ 0.000 & & 0.002 * \\ 0.003 & & 0.001 \\ 0.014 & * & -0.031 \\ 0.005 & & 0.027 \\ -0.014 & * & 0.023 \\ 0.002 & & -0.037 \\ & & 0.004 \\ 0.005 & * * * & 0.010 \\ -0.009 & * * * & \end{array}$

IV, Outcome

$\ln$ (Hourly wage)

College Women

b

0.002

$0.069 *$
-0.110
0.006
$0.036 *$

$-0.025 * *$

$0.012 *$

0.000

0.003

$0.014 *$

0.005

$-0.014 *$

0.001

$0.005 * * *$

$-0.009 * * *$

\begin{tabular}{|c|c|c|c|c|c|}
\hline \multirow{3}{*}{\multicolumn{2}{|c|}{$\begin{array}{l}\text { OLS } \\
\text { ln(Hourly wage }) \\
\text { College Men }\end{array}$}} & \multirow{3}{*}{\multicolumn{2}{|c|}{$\begin{array}{l}\text { IV, First Stage } \\
M_{i} \\
\text { College Men }\end{array}$}} & \multicolumn{2}{|c|}{ IV, Outcome } \\
\hline & & & & $\ln ($ Hour & ly wage) \\
\hline & & & & College & Men \\
\hline 0.014 & $\begin{array}{l}\text { Sig. } \\
* * *\end{array}$ & b & Sig. & $\begin{array}{l}b \\
-0.008\end{array}$ & Sig. \\
\hline 0.002 & & -0.042 & & 0.004 & \\
\hline 0.028 & & 0.092 & & 0.026 & \\
\hline 0.006 & & 0.106 & & 0.010 & \\
\hline-0.008 & & 0.181 & $*$ & -0.006 & \\
\hline-0.037 & $* * *$ & -0.018 & & -0.038 & $* * *$ \\
\hline 0.026 & $* * *$ & 0.014 & & 0.027 & $* * *$ \\
\hline 0.000 & & -0.001 & & 0.000 & \\
\hline 0.018 & $* *$ & -0.025 & & 0.017 & $* *$ \\
\hline 0.002 & & 0.018 & & 0.003 & \\
\hline 0.001 & & 0.011 & & 0.001 & \\
\hline-0.007 & & 0.088 & $* *$ & -0.004 & \\
\hline 0.004 & & -0.005 & & 0.004 & \\
\hline 0.003 & $* * *$ & 0.004 & & 0.003 & $* * *$ \\
\hline-0.010 & $* * *$ & 0.008 & & -0.010 & $* * *$ \\
\hline
\end{tabular}




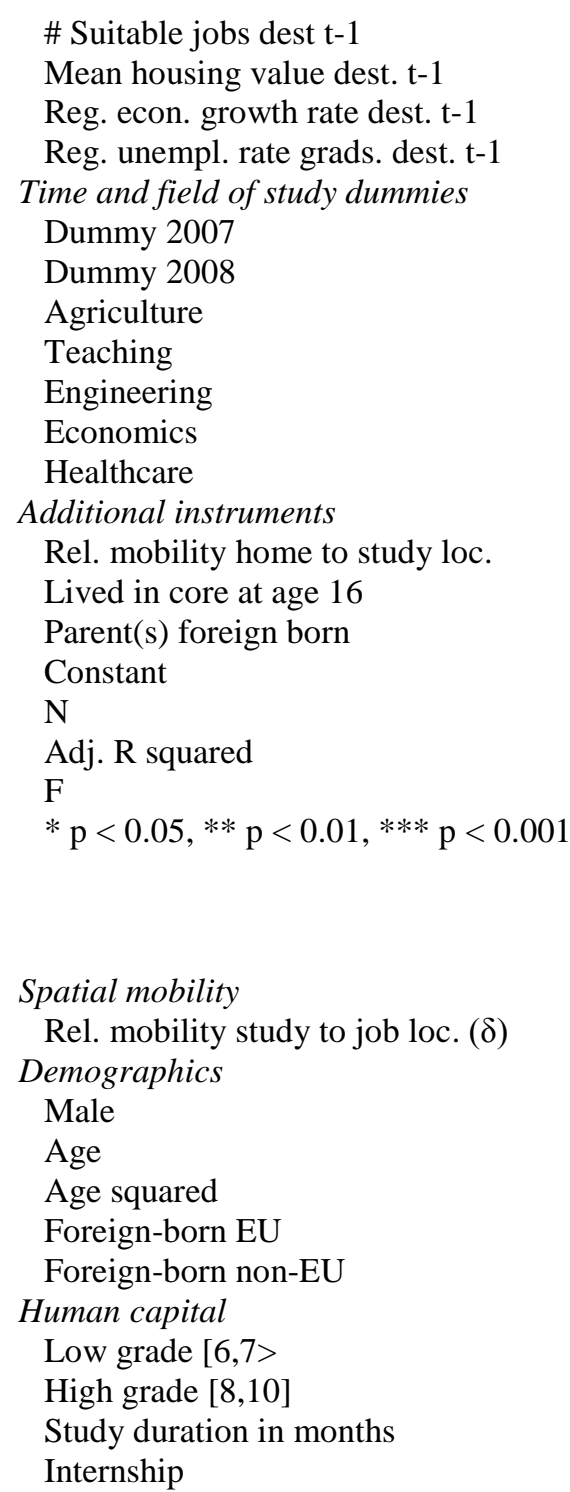

Demographics

Male

Age

Age squared

Foreign-born EU

Foreign-born non-EU

Human capital

Low grade $[6,7>$

High grade $[8,10]$

Study duration in months

Internship

\subsection{9}

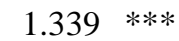

10106

0.058

22.926

IV, Outcome

$\ln$ (Hourly wage)

$\begin{array}{rlrlrl}0.128 & * * * & -0.410 & * * * & 0.121 & * * * \\ 0.009 & * * * & 0.060 & * * * & 0.011 & * * * \\ -0.001 & & 0.021 & * & 0.000 & \\ -0.001 & & -0.002 & & -0.001 & \\ & & & & & \\ 0.032 & * * * & 0.001 & & 0.032 & * * * \\ 0.046 & * * * & -0.006 & & 0.046 & * * * \\ -0.037 & * & -0.174 & * * & -0.041 & * * \\ 0.008 & & 0.027 & & 0.011 & \\ 0.017 & & -0.144 & * & 0.014 & \\ 0.008 & & -0.175 & * * & 0.004 & \\ 0.138 & * * * & -0.123 & & 0.136 & * * * \\ & & & & & \\ & & 0.302 & * * * & & \\ & & 0.030 & & & \\ 2.202 & * * * & -0.007 & & & \\ 7559 & & 7559 & & 7559 & \\ 0.070 & & 0.145 & 0.064 & \\ 22.583 & & 24.438 & 22.089 & \end{array}$

$\ln$ (Hourly wage) $\mathrm{M}_{\mathrm{i}} \ln$ (Hourly wage)

V, First Stage IV, Outcome

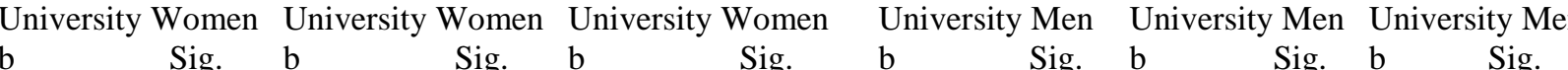
$0.027 * * *$
$-0.019$
$0.024 * * *$
$-0.014$

0.069

$-0.094$

0.003

$\begin{array}{rr}0.506 & * * \\ -0.939 & * * \\ -0.001 & \\ -0.008 & \\ -0.002 & \\ -0.013 & \\ -0.001 & * * \\ -0.014 & \end{array}$

\begin{tabular}{|c|c|c|c|}
\hline \multirow{2}{*}{$\begin{array}{r}0.095 \\
-0160\end{array}$} & & 0.079 & 0.101 \\
\hline & & -0.146 & -0.171 \\
\hline-0.044 & & -0.129 & -0.048 \\
\hline 0.031 & & 0.029 & 0.030 \\
\hline-0.028 & $* *$ & 0.016 & -0.027 \\
\hline 0.014 & & 0.010 & 0.015 \\
\hline 0.000 & & $-0.001 *$ & 0.000 \\
\hline 0.018 & $*$ & 0.004 & 0.018 \\
\hline
\end{tabular}




\begin{tabular}{|c|c|c|c|c|c|c|c|c|c|c|c|c|}
\hline Relevant work exp. & 0.036 & $* * *$ & 0.016 & & 0.037 & $* * *$ & 0.035 & $* * *$ & 0.020 & & 0.036 & $* * *$ \\
\hline Management exp. & 0.007 & & -0.009 & & 0.008 & & 0.031 & $* * *$ & 0.037 & & 0.033 & $* * *$ \\
\hline Study abroad & 0.006 & & -0.013 & & 0.007 & & -0.016 & $*$ & 0.057 & & -0.013 & \\
\hline Internship abroad & 0.010 & & 0.043 & & 0.013 & & 0.018 & $*$ & 0.032 & & 0.020 & $*$ \\
\hline Follow-up education & -0.016 & & -0.044 & & -0.018 & & 0.000 & & -0.010 & & 0.000 & \\
\hline \multicolumn{13}{|l|}{ Transition study to job } \\
\hline Duration finals - questionnaire & 0.003 & $* * *$ & 0.005 & & 0.004 & $* * *$ & 0.005 & $* * *$ & 0.007 & $* *$ & 0.006 & $* * *$ \\
\hline Months unemployed & -0.010 & $* * *$ & 0.007 & & -0.010 & $* * *$ & -0.013 & $* * *$ & 0.002 & & -0.013 & $* * *$ \\
\hline \multicolumn{13}{|l|}{ Regional economic characteristics } \\
\hline \# Suitable jobs dest. t-1 & 0.224 & $* * *$ & -0.782 & $* * *$ & 0.187 & $* * *$ & 0.197 & $* * *$ & -0.740 & $* * *$ & 0.168 & $* * *$ \\
\hline Mean housing value dest. $\mathrm{t}-1$ & 0.011 & $* *$ & -0.227 & $* * *$ & 0.001 & & -0.002 & & -0.082 & $* * *$ & -0.005 & \\
\hline Reg. econ. growth rate dest. t- 1 & -0.008 & & 0.154 & $* * *$ & -0.001 & & -0.002 & & 0.017 & & -0.001 & \\
\hline Reg. unempl. rate grads. dest. t-1 & -0.005 & & -0.062 & $* * *$ & -0.008 & $*$ & 0.004 & & -0.001 & & 0.004 & \\
\hline \multicolumn{13}{|l|}{ Time and field of study dummies } \\
\hline Dummy 2007 & 0.017 & $*$ & 0.046 & & 0.019 & $* *$ & 0.020 & $* *$ & -0.017 & & 0.020 & $* *$ \\
\hline Dummy 2008 & 0.017 & & 0.063 & & 0.021 & $*$ & 0.031 & $* *$ & 0.033 & & 0.032 & $* * *$ \\
\hline Agriculture & -0.034 & $* *$ & -0.411 & $* * *$ & -0.053 & $* * *$ & -0.026 & & -0.325 & $* * *$ & -0.037 & $*$ \\
\hline Engineering & -0.009 & & -0.239 & $* * *$ & -0.019 & & 0.007 & & -0.169 & $* * *$ & 0.001 & \\
\hline Economics & 0.067 & $* * *$ & -0.020 & & 0.066 & $* * *$ & 0.067 & $* * *$ & -0.029 & & 0.067 & $* * *$ \\
\hline Healthcare & 0.065 & $* * *$ & 0.016 & & 0.067 & $* * *$ & 0.104 & $* * *$ & -0.016 & & 0.105 & $* * *$ \\
\hline Humanities & -0.086 & $* * *$ & -0.133 & $* * *$ & -0.093 & $* * *$ & -0.064 & $* * *$ & -0.034 & & -0.065 & $* * *$ \\
\hline Law & 0.030 & $* *$ & -0.050 & & 0.027 & $*$ & 0.009 & & -0.029 & & 0.010 & \\
\hline Natural sciences & -0.008 & & -0.037 & & -0.008 & & 0.013 & & -0.035 & & 0.012 & \\
\hline \multicolumn{13}{|l|}{ Additional instruments } \\
\hline Rel. mobility home to study loc. & & & -0.080 & $* * *$ & & & & & 0.147 & $* * *$ & & \\
\hline Lived in core at age 16 & & & 0.182 & $* * *$ & & & -0.018 & $* *$ & -0.025 & & -0.019 & $* *$ \\
\hline Parent(s) foreign born & -0.023 & $*$ & -0.068 & $*$ & -0.029 & $* *$ & & & -0.063 & & & \\
\hline Constant & 1.339 & $*$ & -5.581 & $* *$ & 1.039 & & 1.105 & & -0.223 & & 1.059 & \\
\hline $\mathrm{N}$ & 4588 & & 4588 & & 4588 & & 3943 & & 3943 & & 3943 & \\
\hline Adj. R squared & 0.142 & & 0.137 & & 0.118 & & 0.138 & & 0.056 & & 0.121 & \\
\hline $\mathrm{F}$ & 24.791 & & 24.326 & & 23.374 & & 18.482 & & 8.442 & & 18.030 & \\
\hline
\end{tabular}


TABLE B.2: College Graduates, LPM and IV-LPM Analysis of Alternative Job Match Outcomes

\begin{tabular}{|c|c|c|c|c|c|c|c|c|c|c|c|c|}
\hline \multirow[b]{2}{*}{ Spatial mobility } & \multicolumn{2}{|c|}{$\begin{array}{l}\text { LPM } \\
\text { p(perm. contr.) } \\
\text { College Total }\end{array}$} & \multicolumn{2}{|c|}{$\begin{array}{l}\text { IV -LPM Outcome } \\
\text { p(perm. contr.) } \\
\text { College Total }\end{array}$} & \multicolumn{2}{|l|}{$\begin{array}{l}\text { LPM } \\
\text { p(full-time) } \\
\text { College Total }\end{array}$} & \multicolumn{2}{|c|}{$\begin{array}{l}\text { IV-LPM Outcome } \\
\text { p(full-time) } \\
\text { College Total }\end{array}$} & \multicolumn{2}{|l|}{$\begin{array}{l}\text { LPM } \\
\text { p(vert. match) } \\
\text { College Total }\end{array}$} & \multicolumn{2}{|c|}{$\begin{array}{l}\text { IV-LPM Outcome } \\
\text { p(vert. match) } \\
\text { College Total }\end{array}$} \\
\hline & $\mathrm{b}$ & Sig. & $\mathrm{b}$ & Sig. & $\mathrm{b}$ & Sig. & $\mathrm{b}$ & Sig. & $\mathrm{b}$ & Sig. & $\mathrm{b}$ & Sig. \\
\hline Rel. mobility study to job loc. $(\delta)$ & 0.000 & & -0.010 & & 0.017 & $* * *$ & -0.006 & & 0.014 & $* * *$ & 0.006 & \\
\hline \multicolumn{13}{|l|}{ Demographics } \\
\hline Male & 0.089 & $* * *$ & 0.089 & $* * *$ & 0.090 & $* * *$ & 0.089 & $* * *$ & 0.056 & $* * *$ & 0.056 & $* * *$ \\
\hline Age & -0.002 & & -0.001 & & 0.060 & & 0.062 & & -0.001 & & -0.001 & \\
\hline Age squared & -0.010 & & -0.010 & & -0.122 & & -0.125 & & -0.001 & & -0.001 & \\
\hline Foreign-born non-EU & -0.047 & & -0.047 & & 0.015 & & 0.015 & & 0.003 & & 0.003 & \\
\hline \multicolumn{13}{|l|}{ Human capital } \\
\hline Low grade $[6,7>$ & -0.018 & & -0.018 & & 0.008 & & 0.008 & & -0.059 & $* * *$ & -0.059 & $* * *$ \\
\hline High grade $[8,10]$ & 0.023 & $* *$ & 0.023 & $* *$ & 0.007 & & 0.007 & & 0.031 & $* * *$ & 0.031 & $* * *$ \\
\hline Study duration in months & 0.000 & & 0.000 & & -0.001 & $* * *$ & -0.001 & $* * *$ & 0.000 & & 0.000 & \\
\hline Relevant work exp. & 0.018 & $*$ & 0.018 & $*$ & -0.018 & $* *$ & -0.018 & $* *$ & -0.001 & & -0.001 & \\
\hline Management exp. & 0.013 & & 0.013 & & 0.001 & & 0.001 & & 0.027 & $* * *$ & 0.027 & $* * *$ \\
\hline Study abroad & -0.015 & & -0.015 & & -0.001 & & 0.000 & & 0.024 & $*$ & 0.024 & $*$ \\
\hline Internship abroad & -0.008 & & -0.007 & & 0.014 & & 0.016 & $*$ & -0.016 & & -0.015 & \\
\hline \multicolumn{13}{|l|}{ Transition study to job } \\
\hline Duration finals - questionnaire & 0.013 & $* * *$ & 0.013 & $* * *$ & 0.002 & $* *$ & 0.002 & $* *$ & 0.001 & & 0.001 & \\
\hline Months unemployed & -0.032 & $* * *$ & -0.032 & $* * *$ & -0.013 & $* * *$ & -0.013 & $* * *$ & -0.011 & $* * *$ & -0.011 & $* * *$ \\
\hline \multicolumn{13}{|l|}{ Regional economic characteristics } \\
\hline \# Suitable jobs dest. t-1 & 0.114 & $* * *$ & 0.110 & $* * *$ & 0.085 & $* * *$ & 0.077 & $* * *$ & 0.118 & $* * *$ & 0.115 & $* * *$ \\
\hline Mean housing value dest. $\mathrm{t}-1$ & 0.020 & $* * *$ & 0.020 & $* * *$ & 0.003 & & 0.004 & & -0.001 & & 0.000 & \\
\hline Reg. econ. growth rate dest. t- 1 & 0.008 & $*$ & 0.008 & $*$ & 0.001 & & 0.001 & & -0.001 & & -0.001 & \\
\hline Reg. unempl. rate grads. dest. t-1 & -0.006 & & -0.006 & & -0.013 & $* * *$ & -0.013 & $* * *$ & 0.001 & & 0.001 & \\
\hline \multicolumn{13}{|l|}{ Time and field of study dummies } \\
\hline Dummy 2007 & 0.041 & $* * *$ & 0.041 & $* * *$ & -0.010 & & -0.010 & & 0.029 & $* * *$ & 0.029 & $* * *$ \\
\hline Dummy 2008 & 0.031 & $* *$ & 0.031 & $* *$ & -0.028 & $* *$ & -0.028 & $* *$ & 0.018 & $*$ & 0.018 & $*$ \\
\hline Agriculture & -0.068 & $* *$ & -0.069 & $* *$ & 0.387 & $* * *$ & 0.385 & $* * *$ & 0.064 & $* * *$ & 0.064 & $* * *$ \\
\hline Teaching & 0.012 & & 0.012 & & 0.212 & $* * *$ & 0.214 & $* * *$ & 0.224 & $* * *$ & 0.224 & $* * *$ \\
\hline Engineering & 0.027 & $*$ & 0.027 & & 0.437 & $* * *$ & 0.436 & $* * *$ & 0.163 & $* * *$ & 0.163 & $* * *$ \\
\hline Economics & -0.011 & & -0.013 & & 0.437 & $* * *$ & 0.434 & $* * *$ & 0.110 & $* * *$ & 0.109 & $* * *$ \\
\hline
\end{tabular}


Healthcare

Additional instruments

Rel. mobility home to study loc.

Lived in core at age 16

arent(s) foreign born

Constant

$\mathrm{N}$

Adj. R squared

$* \mathrm{p}<0.05, * * \mathrm{p}<0.01, * * * \mathrm{p}<0.00$

\section{LPM}

p(hor. matc College Total College Total

Spatial mobility

Rel. mobility study to job loc. $(\delta)$ Demographics

Male

Age

Age squared

Foreign-born EU

Foreign-born non-EU

Human capital

Low grade [6,7>

High grade $[8,10]$

Study duration in months

Relevant work exp.

Management exp.

Study abroad

Internship abroad

Follow-up education

Transition study to job

Duration finals - questionnaire

Months unemployed

Regional economic characteristics

\# Suitable jobs dest. t-1

Mean housing value dest. t-1

Reg. econ. growth rate dest. t- 1
$0.055 * * *$

$0.054 * * *$

0.377

17665

0.059

4.539

Sig. b

$0.054 * * *$

$0.054 * * *$

0.377

17665

0.059

44.531

V-LPM Outcome

$-0.003$

$0.029 * * *$

0.039

$-0.098$

$0.056 *$

0.004

$-0.039 * * *$

0.004

$-0.001 * * *$

$0.020 * * *$

$-0.015 *$

$-0.046 * * *$

$-0.023 * *$

$-0.016$

$-0.001$

$-0.009 * * *$

0.048

$-0.002$

$0.008 * *$ $\begin{array}{rl} & \text { Sig. } \\ -0.055 & * * *\end{array}$

$0.029 * * *$

0.043

$-0.103$

0.058 *

0.002

$-0.039 * * *$

0.005

$-0.001 * * *$

0.019 ***

$-0.013$

$-0.044 * *$

$-0.018 *$

$-0.017$

$-0.001$

$-0.009 * * *$

0.028

0.001

$0.009 * * *$
$-0.002$

$-0.004$

$0.155 * * *$

$0.154 * * *$

$-0.017 *$

$-0.017 *$

0.663
17665
0.056
35.405

0.663

$-0.235$

17665

0.253

0.255

203.328

201.966

IV-LPM Outcome

p(subj. good match) p(subj. good match) College Total College Total

0.003 Sig. b

$0.031 * * *$

0.028

$-0.072$

$-0.030$

$-0.004$

$-0.053 * * *$

$0.021 * *$

$-0.001 * *$

$0.030 * * *$

0.011

$-0.028 *$

$-0.010$

$-0.024 *$

0.000

$-0.016 * * *$

$-0.013$

0.006

0.003

$\begin{array}{rl} & \text { Sig. } \\ -0.006 & \\ 0.031 & * * * \\ 0.030 & \\ -0.075 & \\ -0.030 & \\ -0.004 & \\ -0.053 & * * * \\ 0.021 & * * \\ -0.001 & * * \\ 0.030 & * * * \\ 0.011 & \\ -0.027 & * \\ -0.009 & \\ -0.025 & * \\ & \\ 0.000 & \\ -0.015 & * * * \\ & \\ -0.015 & \\ 0.006 & * \\ 0.003 & \end{array}$

LPM College Total

\begin{tabular}{|c|c|c|c|}
\hline 0.003 & Sig. & -0.031 & $\begin{array}{l}\text { Sig. } \\
* *\end{array}$ \\
\hline 0.048 & $* * *$ & 0.047 & $* * *$ \\
\hline-0.050 & & -0.047 & \\
\hline 0.078 & & 0.074 & \\
\hline-0.010 & & -0.008 & \\
\hline-0.001 & & -0.002 & \\
\hline-0.026 & $* *$ & -0.026 & $* *$ \\
\hline 0.023 & $* * *$ & 0.024 & $* * *$ \\
\hline-0.001 & $* * *$ & -0.001 & $* * *$ \\
\hline 0.002 & & 0.002 & \\
\hline 0.003 & & 0.005 & \\
\hline-0.013 & & -0.012 & \\
\hline-0.010 & & -0.007 & \\
\hline 0.007 & & 0.006 & \\
\hline 0.001 & & 0.001 & \\
\hline-0.019 & $* * *$ & -0.018 & $* * *$ \\
\hline 0.043 & $*$ & 0.031 & \\
\hline 0.007 & $* *$ & 0.009 & $* * *$ \\
\hline 0.003 & & 0.003 & \\
\hline
\end{tabular}




\begin{tabular}{|c|c|c|c|c|c|c|c|c|c|c|c|c|}
\hline \multirow{2}{*}{$\begin{array}{l}\text { Reg. unempl. rate grads. dest. } \mathrm{t}-1 \\
\text { Time and field of study dummies }\end{array}$} & \multicolumn{2}{|l|}{-0.003} & \multicolumn{2}{|l|}{-0.004} & \multicolumn{2}{|l|}{-0.002} & \multicolumn{2}{|l|}{-0.002} & \multicolumn{2}{|l|}{-0.004} & \multicolumn{2}{|l|}{-0.004} \\
\hline & & & & & & & & & & & & \\
\hline Dummy 2007 & 0.013 & & 0.013 & & 0.022 & $* *$ & 0.022 & $* *$ & 0.025 & $* * *$ & 0.025 & $* * *$ \\
\hline Dummy 2008 & 0.001 & & 0.002 & & 0.012 & & 0.012 & & 0.009 & & 0.009 & \\
\hline Agriculture & -0.112 & $* * *$ & -0.118 & $* * *$ & -0.041 & $*$ & -0.042 & $*$ & 0.013 & & 0.009 & \\
\hline Teaching & 0.068 & $* * *$ & 0.071 & $* * *$ & 0.090 & $* * *$ & 0.091 & $* * *$ & 0.026 & $*$ & 0.028 & $*$ \\
\hline Engineering & 0.003 & & -0.001 & & -0.011 & & -0.011 & & 0.075 & $* * *$ & 0.073 & $* * *$ \\
\hline Economics & -0.184 & $* * *$ & -0.191 & $* * *$ & -0.037 & $* * *$ & -0.038 & $* * *$ & 0.010 & & 0.005 & \\
\hline Healthcare & 0.053 & $* * *$ & 0.049 & $* * *$ & 0.012 & & 0.012 & & 0.038 & $* * *$ & 0.035 & $* *$ \\
\hline Rel. mobility home to study loc. & & & & & & & & & & & & \\
\hline Lived in core at age 16 & -0.017 & $*$ & -0.017 & $*$ & -0.018 & $*$ & -0.017 & $*$ & & & & \\
\hline Parent(s) foreign born & -0.034 & $* *$ & -0.037 & $* *$ & & & & & & & & \\
\hline Constant & 0.573 & & 0.563 & & 0.557 & & 0.543 & & 1.568 & $* * *$ & 1.556 & $* * *$ \\
\hline $\mathrm{N}$ & 17665 & & 17665 & & 17665 & & 17665 & & 17665 & & 17665 & \\
\hline Adj. R squared & 0.091 & & 0.079 & & 0.027 & & 0.027 & & 0.035 & & 0.029 & \\
\hline $\mathrm{F}$ & 56.294 & & 56.450 & & 19.084 & & 19.013 & & 23.374 & & 23.582 & \\
\hline
\end{tabular}


TABLE B.3: University Graduates, LPM and IV-LPM Analysis of Alternative Job Match Outcomes

\begin{tabular}{|c|c|c|c|c|c|c|c|c|c|c|c|c|}
\hline \multirow[b]{2}{*}{ Spatial mobility } & \multicolumn{2}{|c|}{$\begin{array}{l}\text { LPM } \\
\text { p(perm. contr.) } \\
\text { University Total }\end{array}$} & \multicolumn{2}{|c|}{$\begin{array}{l}\text { IV_LPM Outcome } \\
\text { p(perm. contr.) } \\
\text { University Total }\end{array}$} & \multicolumn{2}{|c|}{$\begin{array}{l}\text { LPM } \\
\mathrm{p} \text { (full-time) } \\
\text { University Total }\end{array}$} & \multicolumn{2}{|c|}{$\begin{array}{l}\text { IV_LPM Outcome } \\
\text { p(full-time) } \\
\text { University Total }\end{array}$} & \multicolumn{2}{|c|}{$\begin{array}{l}\text { LPM } \\
\text { p(vert. match) } \\
\text { University Total }\end{array}$} & \multicolumn{2}{|c|}{$\begin{array}{l}\text { IV-LPM Outcome } \\
\text { p(vert. match) } \\
\text { University Total }\end{array}$} \\
\hline & $\mathrm{b}$ & Sig. & $\mathrm{b}$ & Sig. & $\mathrm{b}$ & Sig. & $\mathrm{b}$ & Sig. & $\mathrm{b}$ & Sig. & $\mathrm{b}$ & Sig. \\
\hline Rel. mobility study to job loc $(\delta)$ & 0.028 & $* * *$ & -0.003 & & 0.027 & $* * *$ & 0.055 & & 0.024 & $* * *$ & 0.001 & \\
\hline \multicolumn{13}{|l|}{ Demographics } \\
\hline Male & 0.069 & $* * *$ & 0.068 & $* * *$ & 0.089 & $* * *$ & 0.090 & $* * *$ & 0.042 & $* * *$ & 0.042 & $* * *$ \\
\hline Age & 0.220 & $* *$ & 0.232 & $* *$ & 0.261 & $* * *$ & 0.250 & $* * *$ & 0.066 & & 0.075 & \\
\hline Age squared & -0.414 & $* *$ & -0.436 & $* *$ & -0.495 & $* * *$ & -0.475 & $* * *$ & -0.136 & & -0.153 & \\
\hline Foreign-born EU & 0.038 & & 0.037 & & -0.026 & & -0.024 & & 0.028 & & 0.027 & \\
\hline Foreign-born non-EU & -0.051 & & -0.051 & & -0.009 & & -0.009 & & 0.085 & $*$ & 0.086 & $*$ \\
\hline \multicolumn{13}{|l|}{ Human capital } \\
\hline Low grade $[6,7>$ & -0.010 & & -0.011 & & 0.022 & & 0.022 & & -0.096 & $* * *$ & -0.096 & $* * *$ \\
\hline High grade $[8,10]$ & -0.020 & & -0.021 & & -0.027 & $* *$ & -0.027 & $* *$ & 0.105 & $* * *$ & 0.105 & $* * *$ \\
\hline Study duration in months & 0.000 & & 0.000 & & -0.001 & $* * *$ & -0.001 & $* * *$ & 0.000 & & 0.000 & \\
\hline Internship & -0.008 & & -0.008 & & -0.043 & $* * *$ & -0.043 & $* * *$ & 0.086 & $* * *$ & 0.086 & $* * *$ \\
\hline Relevant work exp. & 0.024 & $*$ & 0.025 & $*$ & -0.019 & $*$ & -0.020 & $*$ & 0.063 & $* * *$ & 0.063 & $* * *$ \\
\hline Management exp. & 0.015 & & 0.016 & & 0.037 & $* * *$ & 0.036 & $* * *$ & 0.075 & $* * *$ & 0.076 & $* * *$ \\
\hline Study abroad & -0.029 & * & -0.028 & & 0.049 & $* * *$ & 0.047 & $* * *$ & 0.043 & $* *$ & 0.043 & $* *$ \\
\hline Internship abroad & -0.008 & & -0.006 & & 0.047 & $* * *$ & 0.045 & $* * *$ & 0.089 & $* * *$ & 0.090 & $* * *$ \\
\hline Follow-up education & -0.088 & $* * *$ & -0.089 & $* * *$ & -0.065 & $* * *$ & -0.065 & $* * *$ & 0.067 & $* * *$ & 0.066 & $* * *$ \\
\hline \multicolumn{13}{|l|}{ Transition study to job } \\
\hline Duration finals - questionnaire & 0.012 & $* * *$ & 0.012 & $* * *$ & 0.002 & $*$ & 0.002 & * & -0.001 & & -0.001 & \\
\hline Months unemployed & -0.027 & $* * *$ & -0.027 & $* * *$ & -0.006 & $* *$ & -0.006 & $* * *$ & -0.007 & $* * *$ & -0.007 & $* * *$ \\
\hline \multicolumn{13}{|l|}{ Regional economic characteristics } \\
\hline \# Suitable jobs dest. t-1 & 0.159 & $* *$ & 0.133 & * & 0.109 & $* *$ & 0.130 & $* *$ & 0.276 & $* * *$ & 0.257 & $* * *$ \\
\hline Mean housing value dest. $\mathrm{t}-1$ & 0.024 & $* * *$ & 0.019 & $*$ & -0.008 & & -0.003 & & -0.020 & $* *$ & -0.024 & $* *$ \\
\hline Reg. econ. growth rate dest. $t-1$ & 0.000 & & 0.003 & & 0.013 & $*$ & 0.010 & & 0.000 & & 0.002 & \\
\hline Reg. unempl. rate grads. dest. t-1 & -0.007 & & -0.008 & & -0.010 & $* *$ & -0.009 & * & 0.005 & & 0.005 & \\
\hline \multicolumn{13}{|l|}{ Time and field of study dummies } \\
\hline Dummy 2007 & 0.033 & $* *$ & 0.033 & $* *$ & -0.001 & & -0.002 & & -0.019 & & -0.018 & \\
\hline Dummy 2008 & 0.011 & & 0.013 & & -0.021 & & -0.022 & & 0.009 & & 0.010 & \\
\hline Agriculture & -0.055 & * & -0.067 & $*$ & 0.157 & $* * *$ & 0.169 & $* * *$ & -0.007 & & -0.017 & \\
\hline Engineering & 0.134 & $* * *$ & 0.127 & $* * *$ & 0.262 & $* * *$ & 0.268 & $* * *$ & 0.053 & $* *$ & 0.048 & $*$ \\
\hline Economics & 0.211 & $* * *$ & 0.210 & $* * *$ & 0.264 & $* * *$ & 0.264 & $* * *$ & 0.023 & & 0.023 & \\
\hline
\end{tabular}




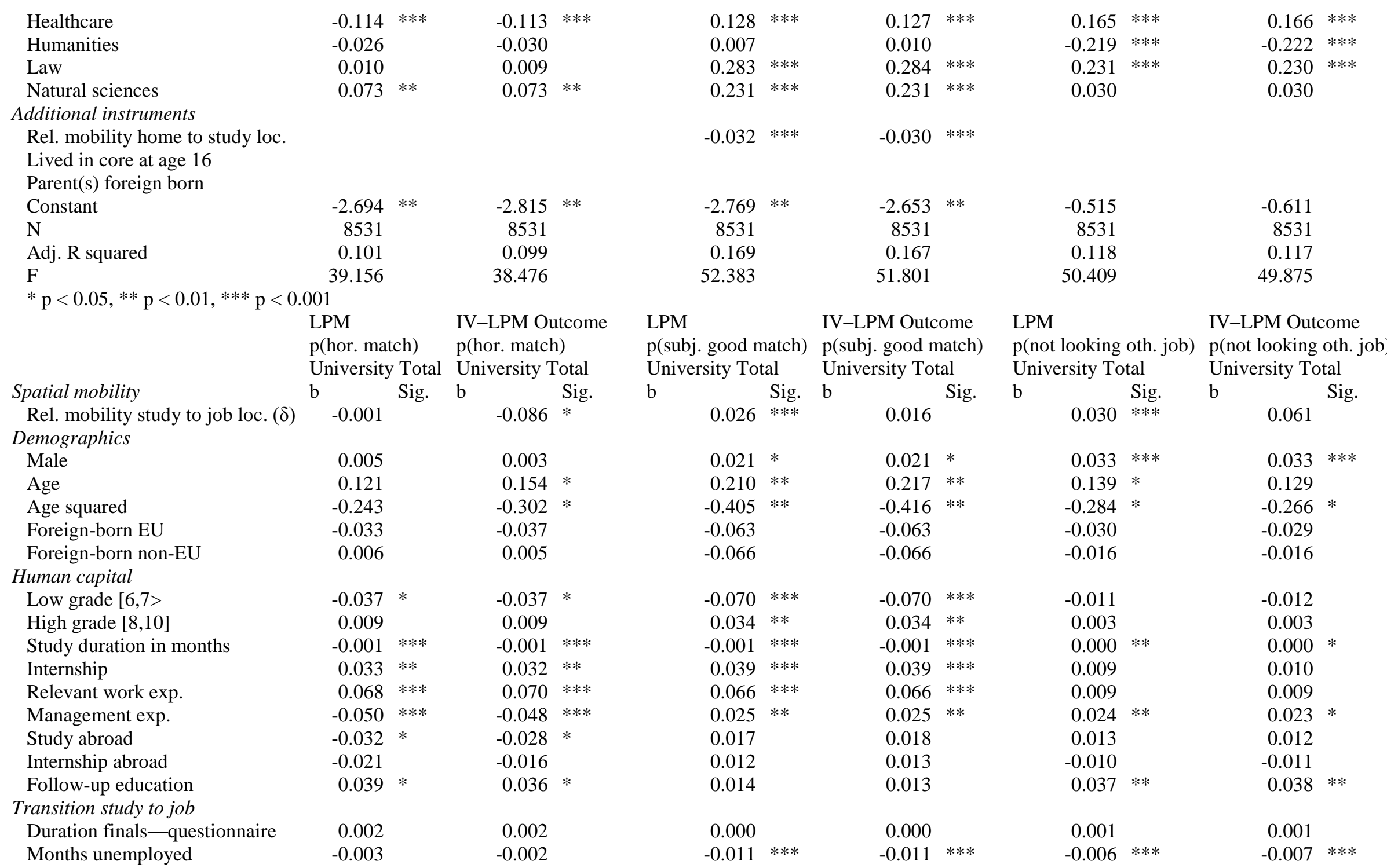


Regional economic characteristics

\# Suitable jobs dest. t-1

$-0.144 * * \quad-0.210 * * *$

$-0.029 * * *$

$-0.015 *$

$0.025 * * *$

$0.033 * * *$

Reg. econ. growth rate dest. t-1

$-0.014 * *$

$-0.017 * * *$

Time and field of study dummies

Dummy 2007

$-0.014$

$-0.045 * *$

$-0.012$

Dummy 2008

$0.122 * * *$

$0.165 * * *$

Engineering

Economics

$0.063 * * *$

Healthcare

Humanities

Law

$0.159 * * *$

$-0.177 * * *$

$0.087 * * *$

Natural sciences

$0.089 * * *$

$-0.039 * *$

$0.088 * * *$

$0.147 * * *$

$0.060 * * *$

$0.162 * * *$

$-0.187 * * *$

$0.083 * * *$

Additional instruments

Rel. mobility home to study loc.

Lived in core at age 16

Parent(s) foreign born

Constant

$-0.040 *$

$-0.722$

8531

0.066

Adj. R squared

20.182

$0.087 * * *$

$\begin{array}{rr}0.044 & \\ -0.009 & \\ -0.005 & \\ -0.002 & \\ & \\ 0.002 & \\ 0.003 & \\ 0.093 & * * * \\ 0.168 & * * * \\ 0.152 & * * * \\ 0.149 & * * * \\ -0.108 & * * * \\ 0.134 & * * * \\ 0.138 & * * *\end{array}$

0.036

$-0.010$

$-0.004$

$-0.002$

$-0.002$

$0.157 * *$

0.003

$-0.007$

$-0.010$

0.003

0.010

$-0.002$

$\mathrm{F}$

$* \mathrm{p}<0.05, * * \mathrm{p}<0.01, * * * \mathrm{p}<0.001$

$-0.047 *$

$-1.062$

8531

0.004

0.001

0.010

$0.089 * * *$

$0.166 * * *$

$0.152 * * *$

$0.150 * * *$

$-0.109 * * *$

$0.134 * * *$

$0.137 * * *$

$0.098 * * *$

$-0.001$

$0.146 * * * \quad 0.153 * * *$

$0.089 * * * \quad 0.090 * * *$

$0.007 \quad 0.006$

$-0.057 * * \quad-0.053 * *$

$0.058 * * * \quad 0.060 * * *$

$0.097 * * *$

$0.097 * * *$

19.878

$-2.090 *$

$-2.160$

$-1.003$

$-0.906$

8531

8531
0.075

8531

853

23.377

22.986

14.066

13.571 